\title{
OS TRADUTORES DO QUIXOTE PUBLICADOS NO BRASIL ${ }^{1}$
}

\section{Silvia Cobelo}

Siempre pienso que una de las cosas felices que me han ocurrido en la vida es haber conocido a Don Quijote.

JORGE LUIS BORGES

O objetivo deste artigo é apresentar um panorama dos resultados das pesquisas historiográficas feitas sobre os tradutores do Quixote, assim como sobre as edições das suas traduções no Brasil. As publicações foram organizadas em um catálogo com detalhes editoriais, e os dados foram tabulados, oferecendo um quadro com a porcentagem de edições por tradutor. Faz-se também uma revisão dos estudos em historiografia da tradução utilizados para elaborar a metodologia utilizada neste trabalho, a qual foi adaptada às condições e ferramentas de pesquisa disponíveis dentro da realidade brasileira.

\section{Estudos em historiografia da tradução}

A história da tradução atrai cada vez mais pesquisadores, enfatizando a necessidade de uma disciplina com metodologia e modelos teóricos adequados. Judith Woodsworth (2005) afirma que somente quando as teorias de orientação estritamente linguística tornaram-se insatisfatórias é que as traduções teriam começado a ser estudadas em seu contexto cultural, histórico e sociológico. $\mathrm{O}$ autor mais conhecido por esse tipo de enfoque é certamente Antony Pym, autor de vários estudos, entre eles o livro Method in Translation History (1998). A escassez de catálogos atualizados de traduções dificulta as pesquisas e a obtenção de dados, tendo ainda o agravante de haver países com pouca tradição bibliográfica. Um dos exemplos dados pelo autor é o próprio Brasil, país que teria, na data em que Pym escreveu o trabalho, referências precárias

\footnotetext{
${ }^{1}$ Este artigo é uma síntese de parte da dissertação de mestrado, Historiografia das traduções do Quixote publicadas no Brasil - provérbios do Sancho Pança, defendida pela autora na FFLCH/USP, 2009. A adaptação da metodologia historiográfica foi apresentada no IV EPOG - FFLCH/USP, 2009. No XVII Congreso de la Asociación Internacional de Hispanistas em Roma, 2010, foi apresentada a comunicação ¿Qué Quijote leen los brasileños?, com um panorama dos tradutores e as edições do Quixote no Brasil. Parte deste artigo foi lido na palestra As traduções do Quixote publicadas no Brasil e seus tradutores, promovida pelo CITRAT/FFLCH - USP, no dia 27 ago. 2010.
} 
para uma história da tradução, embora desde então a pesquisa historiográfica no Brasil tenha tomado impulso ${ }^{2}$.

Pym (1998) chama de "catálogos de tradução" as listas de traduções dentro de um campo específico. Sobre a produção de catálogos, aconselha que sejam feitos da forma mais completa possível, de modo a permitir a busca de informações específicas. O desafio seria conseguir trabalhar com fontes incompletas de forma a converter um catálogo em um corpus útil. Foi dentro dessa abordagem que se elaborou o catálogo das edições do Quixote publicadas no Brasil. Em seu estudo, considera imprescindível a seleção das informações recolhidas. Ao se pesquisar em uma área específica, surgiriam inúmeros dados, especialmente se a pesquisa é feita não só em fontes tradicionais, mas também em fontes secundárias, sendo importante adotar critérios para delimitar períodos, línguas e/ou culturas. Após a confecção das listas, estas podem ser transformadas em curvas de frequência, apontando a distribuição de traduções através do tempo. Os resultados gráficos podem configurar uma organização de dados satisfatória, como se confirma nesta pesquisa.

Pym trata de um tema bastante pertinente para este artigo, que é o da designação de "traduções" incluindo também as reimpressões (ele dá o exemplo de uma mesma tradução reimpressa ou reeditada sempre pela mesma editora, e de uma tradução publicada por várias editoras ${ }^{3}$ ). $\mathrm{O}$ fato de serem encontradas muitas traduções de um mesmo texto, bem como reedições de traduções antigas, poderia ser considerado como um bom índice da demanda do público leitor. Nesse tipo de pesquisa, como ocorreu na investigação das traduções do Quixote, muitas vezes não se conseguem dados referentes, por exemplo, às tiragens e vendas reais, portanto a frequência das reedições geraria um panorama dessa demanda. As reedições de uma tradução antiga tendem a demonstrar sua validade, contestada justamente pelas retraduções.

Para Antony Pym, a importância dos tradutores é evidente, e apesar de admitir que é muito difícil determinar o papel dos mesmos na história da tradução, ele enfatiza a necessidade de se considerar a existência de uma pessoa, de carne e osso, com as

\footnotetext{
${ }^{2}$ O autor menciona, como exceções, os trabalhos de John Milton (1993), José Paulo Paes (1990) e o trabalho de Lia Wyler, A tradução no Brasil. Dissertação de mestrado em Comunicação e Cultura. Rio de Janeiro: Escola de Comunicação da Universidade Federal do Rio de Janeiro, 1995. No último decênio, a bibliografia sobre historiografia aumentou bastante no Brasil: foram lançados pelo menos dois volumes temáticos (Crop 6, em 2001, e Tradução em Revista 5, em 2008), além deste (Tradução em Revista 8) que inclui o presente trabalho e da publicação de artigos em periódicos pluritemáticos e coletâneas; estudos foram desenvolvidos, comunicações apresentadas em congressos, teses e dissertações defendidas. $\mathrm{O}$ Encontro de Tradutores, que teve sua décima edição nacional e quarta edição internacional.

${ }^{3}$ Pym (1998:79-80).
} 
angústias, necessidades, defeitos e qualidades de um ser humano por trás de toda obra traduzida (Pym, 1998: 159-160).

Em um artigo recente, Humanizing Translation History (2008), o teórico afirma que o estudo de tradutores tende a mostrar que eles geralmente fazem mais do que traduzir, "they engage in many aspects of cross-cultural communication" (Pym, 2008: 23). Para ele, a história dos tradutores deveria ser considerada como um princípio válido de organização, como ocorre com os autores e seus textos fontes, ou os estudos de língua fonte versus língua ou cultura meta. O problema é que seria muito difícil descobrir dados de tradutores como indivíduos; geralmente o que se conseguiria, como também aconteceu nesta pesquisa, seria a produção de longas listas, geralmente limitadas a títulos bibliográficos, datas de nascimento e referências ocasionais, exigindo bastante trabalho e tempo reunir elementos para uma biografia. Em compensação, ao serem analisadas, essas pesquisas revelariam não só um "hidden labyrinth of textual history but also, indirectly, a few of the historical reasons for the longstanding suppression of translators as significant cultural figures" (2008: 10).

Em outro artigo, Poupaud, Pym e Simón (2008) avaliam alguns caminhos para a obtenção de dados historiográficos. Um deles é o portal da UNESCO, Index Translationum, outro é o Electre, um portal pago, destinado a profissionais da indústria do livro e o terceiro mencionado, de interesse para este trabalho, é o portal de vendas on-line de livros, Amazon.com.

Os pesquisadores então optaram por utilizar, como fonte de pesquisa, o portal Amazon.com. O problema encontrado pelos autores é que o portal não teria sido desenhado para ser uma ferramenta de pesquisa em tradução, portanto apresentaria algumas limitações. Mesmo assim consideraram esse portal uma ferramenta útil, na convicção de que, utilizando filtros corretos para a investigação, poderiam ser obtidos dados exaustivos sobre títulos disponíveis. Uma estratégia semelhante foi utilizada nesta pesquisa com resultados bastante satisfatórios.

Segundo Heloísa Cintrão (2006: 293), as ferramentas provindas da tecnologia da Internet seriam parte dos recursos de pesquisa e documentação para tradutores. Em sua tese ela cita não só o Google e seus principais recursos, mas também dicionários online, memórias de tradução e listas de tradutores como fontes de consulta. Alerta que a Internet pode ser usada como uma imensa enciclopédia, desde que não recorramos a ela “de maneira ingênua, aprendendo certos parâmetros de avaliação crítica e aplicando certos critérios que podem nos dar alguma garantia de confiabilidade do resultado 
obtido". Essa abordagem para consultas à Internet foi usada na pesquisa das edições e nos estudos feitos para a elaboração das entrevistas com os tradutores.

Outro conceito bastante pertinente para este trabalho foi o de paratexto e o seu papel na leitura. Martins (1999: 193) faz uma distinção entre paratextos e metatextos, especificando que os primeiros são os elementos inseridos na edição, junto com o texto: "título, a folha de rosto, as orelhas, as quatro capas, o(s) prefácio(s) e até mesmo elementos inseridos nos interstícios da obra, como títulos de capítulos e notas de rodapé". Os metatextos, por sua vez, são elementos fora da edição, "transmitidos através da mídia (como entrevistas e palestras, por exemplo) ou de comunicações particulares (correspondência, diários, etc.)".

Em uma comunicação no XI Congresso Internacional da ABRALIC, realizado em 2008, em São Paulo, Martins apresentou o portal Escolha seu Shakespeare, um instrumento para assessorar o público a localizar a tradução desejada, "a escolher o 'seu' Shakespeare dentre as edições disponíveis" (2008: 4, aspas da autora) ${ }^{4}$. Os dados biográficos dos tradutores foram quase todos coletados através de entrevistas com os próprios ou com pessoas próximas destes. O projeto considera como características da tradução a dicção, estilo, registro, esquema rímico e métrico, e como características da edição, se a mesma é bilíngue, se faz parte de alguma coleção ou série, seus paratextos, destaque dado ao nome do tradutor, se é informada a edição (ou edições) em inglês usada para a tradução. A recepção crítica é embasada em resenhas e matérias divulgadas na mídia, mas também consideram “declarações, avaliações e comentários publicados ou obtidos por meio de entrevistas" (Martins, 2008: 4). A ficha de análise das edições para a produção do catálogo apresentado aqui neste artigo está basicamente referenciada nas pesquisas dessa autora.

\section{A metodologia adaptada à realidade brasileira}

Ao iniciar a pesquisa historiográfica das traduções e tradutores do Quixote, encontrou-se uma grande dificuldade na obtenção de dados. Foram infrutíferas as tentativas de encontrá-los em órgãos como a Câmara Brasileira de Livros (CBL), portais

\footnotetext{
${ }^{4}$ O portal contém uma base de dados constituída por 171 traduções brasileiras diferentes das 37 peças do dramaturgo, todas feitas a partir de um texto original integral. As descrições e os resultados da análise do projeto tradutório e editorial e cada edição foram incorporados a fichas catalográficas individuais, disponíveis para consulta pelas seguintes palavras-chave: Título da obra em inglês, Título da obra em português, Nome do tradutor, Características da tradução, Ano de publicação e Editora. Disponível em: http://www.letras.puc-rio.br/shakespeare/. Acesso em 25 out. 2010.
} 
de bibliotecas públicas ou arquivos das próprias editoras - muitas das quais foram vendidas ou fundidas com outras, não dispunham mais de arquivos antigos ou não os disponibilizaram.

A elaboração do catálogo das 72 edições do Quixote publicadas no Brasil foi baseada em buscas no portal vendas de livros usados, Estante Virtual, conhecido na mídia como "Google dos livros". Em recente entrevista à Danelon (2009), André Garcia, jovem empreendedor que criou a empresa em 2005, afirma que as vendas, que montaram a R\$ 36 milhões só em 2009, continuam crescendo. Na página inicial desse portal as informações são atualizadas constantemente. No dia consultado ( 25 de agosto 2010), ofereciam mais de 24 milhões de livros, ultrapassando 100 mil acessos por dia. Declaram reunir um acervo de 1.782 sebos e livreiros (10\% fora do Brasil) dispersos em 320 cidades do Brasil. O portal aceita, sem custo algum ao interessado, uma quota de cem livros de pessoas físicas e atualmente instalou um sistema de trocas de livros, aumentando ainda mais o universo pesquisado.

No campo de busca existem as seguintes opções: autor ou título, autor, título, editora, descrição. A pesquisa pode ser refinada com palavras chave e novamente aparecem as opções acima, sendo possível limitar a busca aos resultados já conseguidos. Por exemplo, ao digitar "dom Quixote" aparecem 2.366 obras. Ao refinar a busca com a editora "José Olympio" o número é reduzido para 82. Os números obviamente sofrem alterações contínuas.

Para a elaboração do catálogo seguiram-se os seguintes passos:

1) Busca pelo nome da obra.

2) Análise de cada entrada. Descartaram-se os livros que não estão nas estantes de Literatura Estrangeira, Literatura Espanhola, Coleções, Livros Raros e Outros Assuntos. Com isso eliminaram-se as adaptações, biografias e estudos críticos.

3) Análise detalhada de cada descrição. Compilação de informações sobre cada edição.

4) Por não existir um campo "tradutor", e por falta de informações na descrição, muitas vezes foi necessário um contato direto com o livreiro/vendedor da obra por e-mail ou telefone para checar informações faltantes.

5) Para maior precisão na pesquisa, ativou-se uma verificação cruzada, utilizando-se o campo de editoras nos resultados encontrados para verificação de possíveis erros ou omissões. As informações foram 
finalizadas com pesquisas nas ferramentas do Google e outros buscadores, além de contato com editoras.

6) Organização dos dados obtidos em planilha Excel e obtenção de gráficos e estatísticas.

As edições foram analisadas, considerando-se o que foi possível verificar diretamente, e as coletas de dados privilegiariam aqueles referentes à edição: ano de publicação, editora, título em português, nome do tradutor, ilustrações, número de páginas, volumes, reimpressões e os paratextos apresentados. Para cada edição ensaiouse um breve panorama da editora responsável pela publicação utilizando na maioria das vezes o excelente livro de Hallewell (2005), e uma breve nota biográfica dos autores dos paratextos e ilustradores.

A pesquisa sobre os seis tradutores foi elaborada com as ferramentas de busca do Google, Bing, Exalead; procurando-se o nome do tradutor colocado entre aspas, e na busca relacionada só com a tradução da obra de Cervantes, adicionando-se o nome da obra, "Quixote". Também foi usado o recurso de pesquisa avançada, delimitando o país e/ou a língua, no caso, português. A utilização, com os mesmos critérios, dos mecanismos de busca do Google acadêmico e Google livros para obter dados biográficos, assim como livros traduzidos e/ou escritos, foi uma estratégia bastante útil para a pesquisa dos tradutores do século XIX e XX, os quais não apareceram nos canais usuais, como os tradutores contemporâneos. No caso dos tradutores do século XXI, em especial Sergio Molina, ocorreu um problema inverso: surgiram mais entradas do que era possível analisar, e foi dada preferência aos dados mais fidedignos da excelente entrevista feita por Villa, Benedetti e Hirsch (2003) e publicada em Cadernos de Literatura em Tradução 5. Encontraram-se breves biografias desses tradutores nos portais de algumas editoras — apenas os tradutores Nougué e Sánchez estão no dicionário Ditra ${ }^{5}$. A pesquisa foi complementada com entrevistas com os quatro tradutores vivos, sendo que Eugênio Amado também respondeu por seu pai, Milton Amado, já falecido. Buscaram-se ainda metatextos sobre as traduções em si e sobre os tradutores, para melhor delinear o panorama da recepção no Brasil da maior obra de Cervantes.

\footnotetext{
${ }^{5}$ Disponível em: http://www.dicionariodetradutores.ufsc.br/pt/index.htm. Acesso em 02 jul. 2010.
} 


\section{Os tradutores do Quixote publicados no Brasil}

A recepção do Quixote no Brasil está relacionada com seus tradutores e suas traduções. Pensando na pergunta de Hurtado Albir (2007) - “QQuién traduce?”, pesquisou-se a biografia dos tradutores, com foco especial em suas atuações na profissão e em especial na tradução do Quixote. Duas traduções foram feitas por portugueses; os Viscondes de Castilho e Azevedo, junto com Pinheiro Chagas, são responsáveis pela primeira tradução assinada da obra para o português, publicada em Lisboa no final do século XIX, e a tradução de Aquilino Ribeiro de 1954. Existem quatro traduções brasileiras, duas delas feitas no século XX. A primeira, assinada por Almir de Andrade e Milton Amado, foi encomendada pela editora José Olympio e publicada em 1958, e a segunda, de 1983, teve como responsável Eugênio Amado. As outras duas foram preparadas para o quarto centenário da publicação do primeiro livro, celebrado em 2005: a tradução bilíngue da editora 34, feita por Sérgio Molina, e o trabalho a quatro mãos realizado por Carlos Nougué e José Luis Sánchez.

\section{A tradução Viscondes/Chagas}

A história do Quixote para o português inicia-se com o fato insólito da sua tradução tardia para esse idioma. Durante 179 anos a obra teria sido lida em espanhol em Portugal, em uma época de bilinguismo luso-castelhano e em que o espanhol havia adquirido status de "língua de cultura" nesse país, conforme estudo feito por Abreu (1997: 61-105) ${ }^{7}$. No mesmo ano da primeira publicação de Madri, em 1605, são publicadas em Lisboa três edições da obra em espanhol ${ }^{8}$; só em 1794 o Quixote é traduzido ao português "vulgar". Essa tradução anônima foi reeditada três vezes. A primeira reedição foi impressa em Paris pela Pillet Aîné em 1830, a segunda em Lisboa pela Typografia Universal no ano de 1853 com outro título: História de D.Quixote de la

\footnotetext{
${ }^{6}$ Hurtado Albir (2007:29-30): "Nos referimos ahora a los conocimientos que ha de poseer el traductor. La primera respuesta que suele darse es que el traductor ha de saber lenguas, que ha de tener conocimientos lingüísticos. Pero esta respuesta hay que matizarla: ¿Tiene que tener el mismo nivel de conocimientos en la lengua de partida que en la lengua de llegada? [...] ¿necesita ser el traductor teórico de las lenguas o un conocedor de la Lingüística? La primera cuestión que hay que considerar es que el traductor necesita una competencia de la comprensión en la lengua de partida y una competencia de comprensión en la lengua de llegada; [...] Sin embargo, no basta con los conocimientos lingüísticos; el traductor ha de poseer también conocimientos extralingüísticos: sobre la cultura de partida y de llegada, sobre el tema del que se trata el texto que está traduciendo, etc.”.

${ }^{7}$ Estuda-se esse fato de maneira mais aprofundada no artigo A tradução tardia do Quixote em Portugal. (Cobelo, 2010a).

${ }^{8}$ Cervantes publicou El Ingenioso Hidalgo Don Quijote de la Mancha em 2005 e El Ingenioso Caballero Don Quijote de la Mancha em 1615. Em estudos hispânicos as duas partes são conhecidas como primeiro livro, com 52 capítulos, e segundo livro, com 74.
} 
Mancha. Cañede (2007: 59 e 2003: 190) cita em nota outra edição dessa mesma tradução anônima, editada em Porto, Portugal em 1858. ${ }^{9}$

A primeira tradução assinada surge somente no final do século XIX, em 1876/78. Essa tradução, a mais publicada até hoje na língua portuguesa, é conhecida como a tradução "dos Viscondes", iniciando talvez uma tradição de injustiças editoriais e omissões de créditos autorais nas traduções do Quixote, algo que perdura nas edições publicações da obra até hoje.

António Feliciano de Castilho (1800-1875) ${ }^{10}$, visconde de Castilho, é o primeiro tradutor do Quixote. Ele perdeu a visão aos seis anos, sequela de um surto de sarampo em sua cidade natal, Lisboa. Foi autor de mais de dez livros e também traduziu obras do latim, francês e inglês antes da sua derradeira tradução, o início do Quixote ${ }^{11}$. É realmente uma produção impressionante, tendo em vista que na época não havia recurso algum para deficientes visuais ${ }^{12}$. Ele morreu aos 75 anos, um ano antes do lançamento da edição do Quixote em 1876. Abreu (1997:254) informa que o tradutor chegou ao capítulo $\mathrm{XXV}^{13}$ do primeiro livro.

Após a morte do Visconde de Castilho surge em cena Francisco Lopes de Azevedo Velho de Fonseca Barbosa Pinheiro Pereira e Sá Coelho (1809-1876) ${ }^{14}$, Visconde de Azevedo. Ao assumir a tradução, ele tinha 66 anos de idade, e morreria um ano depois, no lançamento do primeiro livro do Quixote. Pelo tempo que dedicou ao trabalho é muito improvável que tenha ido além do primeiro livro.

\footnotetext{
${ }^{9}$ Cañede (2007: 59) e (2003: 190) cita em nota uma tradução anônima editada em Porto, Portugal, 1858. Não fornece referências em nenhum dos dois artigos que cita essa edição. Contatada via e-mail, prometeu enviar em breve alguma bibliografia.

${ }^{10}$ Ver mais em http://www.apec.org.pt/castilho.htm. Acesso em 8 jul. 2009.

${ }^{11}$ A lírica, de Anacreonte; Amores, de Ovídio; Geórgicas, de Virgílio; Médico à força, Tartufo, $O$ avarento, Doente de cisma, Sabichonas e Misantropo, todos de Molière; O sonho de uma noite de verão, de Shakespeare; Fausto, de Goethe. Segundo os portais consultados, ele teria sido criticado por traduzir Fausto partindo de uma tradução francesa e por traduzir Shakespeare sem saber inglês.

${ }^{12}$ No Dicionário Histórico de Portugal informam que ele teve que estudar ouvindo a leitura de textos e sendo obrigado a ditar toda a sua obra literária. Aprendendo somente pelo que ouvia ou lhe diziam, Castilho conseguiu alcançar razoável erudição no latim e nas humanidades clássicas, o conhecimento superficial de algumas línguas, e o conhecimento aprofundado da língua portuguesa, que lhe permitiu distinguir-se como poeta e prosador. Disponível em: http://www.arqnet.pt/dicionario/castilhoantoniof.html. Acessado em 8 jul. 2009.

${ }^{13} \mathrm{Ou}$ XXXV, segundo matéria no artigo publicado no jornal O Commercio do Porto. Abreu (1997:254).

${ }^{14}$ Portal Português. Disponível em: http://www.jf-mazarefes.com/?m=historia\&id=554. Acesso em 8 jul. 2009.
} 
Abreu (1994) inclui um terceiro tradutor dessa edição do Quixote, o lisboeta Manuel Pinheiro Chagas (1842-1895), tradutor de parte do segundo livro e autor do prefácio $^{15}$, que infelizmente não acompanhou nenhuma das edições estudadas.

Pinheiro Chagas foi bastante prolífico: publicou onze romances, seis peças de teatro, dez obras como historiador e alguns poemas. Jornalista, foi diretor de vários periódicos de Lisboa. Eleito várias vezes deputado, chegou a ser nomeado Ministro da Marinha e Ultramar ${ }^{16}$. Também atuou como professor de Literatura Clássica no Curso Superior de Letras e ainda teve tempo para traduzir obras do inglês, como a segunda tradução para o português de Robinson Crusoé ${ }^{17}$ e algumas obras de Julio Verne.

Sobre essa tradução, Abreu (1994:82-83) cita Jorge Peixoto ${ }^{18}$, que a denomina “Castilho-Azevedo-P.Chagas”. Os estudos feitos indicam que, apesar de não figurar como nos créditos das edições brasileiras da tradução mais publicada em português ${ }^{19}$, Pinheiro Chagas deve ter traduzido a maior parte da obra, possivelmente todo o segundo livro. É proposto aqui que essa tradução passe a ser denominada como Viscondes/Chagas.

A primeira edição dessa tradução no Brasil foi feita pela Editora Cultura, São Paulo, em 1942/43, em dois volumes e capa dura. Teve 48 reimpressões (e em vários casos, também houve reedição) por várias casas editoriais, com apresentações variadas: volumes únicos ou dois volumes, capa dura ou brochura, com ou sem os mesmos paratextos e ilustrações, como pode ser verificado no catálogo das edições brasileiras do Quixote que será visto neste trabalho.

\section{A tradução de Almir de Andrade e Milton Amado}

Algo similar ocorreu no Brasil com a primeira tradução brasileira do Quixote, assinada por Almir de Andrade (primeiro livro), e Milton Amado (segundo livro). Almir de Andrade nasceu no Rio de Janeiro em 1911; era escritor, filósofo e tradutor, entre outras atividades. Na faculdade de Direito iniciou amizade com vários intelectuais

\footnotetext{
${ }^{15}$ Parte desse prefácio pode ser apreciada em ABREU (2006:305-306) e no subcapítulo, O prefácio de Pinheiro Chagas (1876) em ABREU (1997:82-92).

${ }^{16}$ Dados de Wikipédia. Disponível em: http://pt.wikipedia.org/wiki/Manuel Joaquim Pinheiro Chagas. Acesso em 9 jul 2009.

${ }^{17}$ DEFOE, Daniel. A vida e as aventuras de Robinson Crusoé... Tradução de Pinheiro Chagas.Paris, Lisboa: Guillard, Aillaud \& Cia, [189-?].

${ }^{18}$ PEIXOTO, Jorge. Bibliografia das edições e traduções do D. Quixote publicadas em Portugal. Boletim Internacional de Bibliografia Luso-Brasileira. Vol. 2. Lisboa: Fundação Calouste Gulbenkian, p. 597622, 1961.

${ }^{19}$ Dado confirmado em Portugal por Abreu (1994: 255) e no Brasil, pelos resultados desta pesquisa.
} 
importantes da época, como San Tiago Dantas, Hélio Viana e Vinícius de Moraes. ${ }^{20}$ Segundo Losso, "Almir de Andrade fundou e dirigiu a publicação Cultura Política, revista editada e publicada pelo Departamento de Imprensa e Propaganda (DIP) entre 1941 e 1945" (2006: 96).

Traduziu obras escritas em inglês e francês ${ }^{21}$, mas não foi encontrada nenhuma obra em espanhol por ele vertida além do Quixote. Segundo comunicação pessoal de seu amigo João Ricardo Moderno, atual presidente da Academia Brasileira de Filosofia, Almir de Andrade não teria terminado a tradução do Quixote por ter sido chamado para trabalhar como subchefe da Casa Civil do presidente Getúlio Vargas em 1951. Participou do governo até o final, inclusive teria sido uma das testemunhas presentes no Palácio do Catete em 1954, no fatídico dia do suicídio do presidente. Apesar de aparecer como único tradutor do primeiro livro, sabe-se que ele não terminou os 52 capítulos, tarefa que coube a Milton Amado, que inclusive revisou a segunda e a terceira edições, quadruplicando o número de notas.

Milton Amado, nascido em 1913 em Figueira de Rio Doce, hoje Governador Valadares, foi para Belo Horizonte trabalhar em um importante jornal de Minas, $O$ Diário. Atuou toda sua vida como jornalista e cronista em vários jornais e depois como publicitário na agência Norton, até ser fulminado por uma precoce morte aos 61 anos, em 1974. Mesmo sem ter frequentado escola de idiomas, Milton Amado manteve sempre uma carreira de tradutor em paralelo. A partir de 1942, traduziu mais de trinta livros do inglês, francês e espanhol, inclusive títulos famosos que aparecem em inúmeras citações bibliográficas ${ }^{22}$.

Antes do Quixote, obra que transpôs para o português aos 38 anos, ele já havia traduzido toda a poesia de Edgar Allan Poe ${ }^{23}$, fato que o deixou conhecido como um excelente tradutor de poesia; portanto, não foi por acaso que as poesias contidas no

\footnotetext{
20 Informações retiradas do portal Português do Brasil. Disponível em: http://www.portuguesdobrasil.net/vinicius_de_moraes.htm. Acesso em 10 jul. 2009.

${ }^{21}$ Entre suas traduções, aparecem duas obras do escritor alemão Emil Ludwig, $O$ mediterrâneo (1943) e Freud desmascarado (1948) e uma obra de Leon Tolstoi, Os cossacos (1942), mas se acredita que foram traduzidas a partir de uma tradução francesa, algo comum no panorama editorial da época. As obras em inglês: A psicanálise ao alcance de todos (1940) de Joseph Jastrow, A ciência da vida (1940) de HG Welles, Huxley \& GP Welles, O romance da medicina (1942) de Logan Clendening, O plano Beveridge (1943) de William Beveridge, os quatro volumes da Pequena enciclopédia de conhecimentos gerais (1950/53/55) organizada pelo professor escocês Hyman Levy, Viagens de Guliver (1950) de Jackson Swift. As obras em francês: Indiana (1943) e Mauprat (1945) de George Sand.

${ }^{22}$ Algumas obras: A arte de amar (1960) de Erich Fromm, Viagem ao Espírito Santo e Rio Doce (1974) de Saint-Hilaire e a obra, A sociedade democrática [aberta] e seus inimigos (1959/1975) de Karl Popper, além das outras citadas no texto.

${ }^{23}$ POE, Edgar A. Ficção completa, poesia \& ensaios. Oscar Mendes e Milton Amado. Rio de Janeiro: Aguilar, 1944/1965.
} 
Quixote ficaram sob sua responsabilidade. Ivo Barroso (1998) comparou nove traduções de "The Raven" de Poe ${ }^{24}$, elegendo a versão do primeiro tradutor brasileiro do Quixote como "a grande tradução do poema" (Barroso, 1998:23). Além de traduzir o segundo livro da grande obra de Cervantes ele também foi o tradutor de todas as poesias do primeiro, como confirma a nota da edição de $1952^{25}$ e os créditos nas notas de rodapé das outras edições consultadas. Milton Amado traduziu outros autores consagrados após o Quixote, como Tolstoi, Daphne du Maurier, Dickens e Pär Lagerkvist, Nobel de Literatura em 1951.

As pesquisas apontam Milton Amado como o verdadeiro responsável pela excelência da edição luxuosa da José Olympio em 1952 (231 notas), especialmente após sua rigorosa revisão em 1954 (mais de 872 notas) e 1958 (mais de 931 notas) ${ }^{26}$. Apenas observando a diferença entre o número de notas já é possível perceber seu extenuante trabalho e cuidado com o texto. Nessa modalidade de paratexto, Amado revela suas opções tradutórias, muitas vezes oferecendo o texto na versão original em espanhol e nas duas traduções portuguesas, a Viscondes/Chagas e a de Benalcanfor ${ }^{27}$. José Olympio edita a obra pela última vez em 1973, e depois a tradução é editada cinco vezes pela Ediouro em dois e três volumes (a partir de 2002), com menos da metade das notas (406). As edições atuais não incluem o prefácio do folclorista Luís da Câmara Cascudo nem a introdução de José Brito Broca, e os dois tradutores aparecem, erroneamente, como se tivessem assinado em conjunto a tradução integral de toda a obra.

\section{A tradução de Aquilino Ribeiro}

O escritor português Aquilino Ribeiro (1885-1963) assina mais de 70 obras, entre contos, novelas, romances, estudos etnográficos, biografias, ensaios, impressões de viagem e literatura infantil. Teria começado a traduzir muito cedo, e de maneira

\footnotetext{
${ }^{24}$ Ivo Barroso comparou duas traduções para o francês e sete em português. As traduções estudadas foram: Charles Baudelaire (1853), Stéphane Mallarmé (1888), Machado de Assis (1883), Emílio de Meneses (1917), Fernando Pessoa (1924), Gondin da Fonseca (1928), Milton Amado (1943), Benedito Lopes (1956) e Alexei Bueno (1980). O livro tem uma excelente introdução de Carlos Heitor Cony, também apreciador de Milton Amado como tradutor de poesia.

${ }^{25}$ Nota do Editor: "Estas poesias que abrem o Livro I, traduzidas por Milton Amado" (Cervantes, 1952: 111 , itálicos da edição).

${ }^{26}$ Colocou-se o termo "mais de" pois Milton Amado tinha uma maneira peculiar de fazer notas, como pode ser visto na entrevista feita sobre ele com seu filho. Uma nota muitas vezes é subdividida em a, b, c..., etc.

${ }_{27}$ CERVANTES, Miguel de. O engenhoso fidalgo D. Quixote de la Mancha. Tradução Visconde de Benalcanfor, 2 volumes. Lisboa: Francisco Arthur da Silva, 1877/78.
} 
anônima, antes mesmo de estrear como autor aos 28 anos com seu livro de contos, segundo conta em seu livro de memórias, Um escritor confessa-se $e^{28}$. Ele traduzia mesmo de línguas que conhecia pouco, como descreve Henrique Almeida (2006:_130): “Com dicionário e gramática em punho, ajudado pela tradução francesa, verte o romance [Il Santo, de Antonio Fogazzaro] para Português". Logo depois traduziria Tolstoi, Mantegazza e Dubut de Laforest. Almeida informa que Aquilino deixou o seminário de Beja aos 18 anos, lugar onde obteve a sua formação humanística, a qual lhe permitiria ler textos originais escritos em latim, grego, francês, castelhano e galego. Ribeiro, depois de traduzir o Quixote em $1954,{ }^{29}$ foi responsável, quatro anos depois, pela primeira tradução ao português da versão integral de outra obra de Cervantes, as Novelas exemplares $(1958)^{30}$.

Maria Fernanda de Abreu (2006) afirma que o Quixote de Aquilino Ribeiro, “mais do que uma tradução é uma 'versão', e ele próprio assim a chamou” (2006:312, aspas da autora). Mais adiante a autora chama essa tradução de "reescrita". ${ }^{1}$ No prefácio da obra, Ribeiro se pergunta se seria possível "nacionalizar"32 o Quixote:

\footnotetext{
${ }^{28}$ RIBEIRO, Aquilino. Um escritor confessa-se. Lisboa: Bertrand, 1972.

${ }^{29}$ Nota 10 de Almeida (2006:135): "1 $1^{\text {a }}$ edição de Dom Quixote de La Mancha - Tradução e estudo de Aquilino Ribeiro, edição de luxo, ilustrada por Lima de Freitas, 2 volumes, 1954. Foi editada na mesma altura uma separata de poucos exemplares, "D. Quixote e o seu Autor", que Aquilino ofereceu aos amigos. [...] Note-se que na edição de luxo, de 1954, Aquilino faz demoradas apreciações das traduções até então existentes".

${ }^{30}$ Nota 12 de Almeida (2006:135): “A obra Novelas exemplares - Tradução e estudo de Aquilino Ribeiro, edição ilustrada, de luxo, editada em Lisboa, 1958".

Em 1967 é publicada pela Livraria Bertrand. A obra ainda não foi traduzida integralmente no Brasil.

${ }^{31}$ A autora esclarece melhor no parágrafo seguinte o que seria essa "versão/reescrita": "Pouco tempo depois, Ribeiro traduz igualmente as Novelas exemplares, aproveitando não só para "corrigir" o escritor que admirava mas a quem apontava deficiências estilísticas e gramaticais, como também para o manipular ideologicamente" (Abreu, 1997: 312, itálicos e aspas da autora). Nesse sentido, Henrique Almeida (2006) também considera a tradução de Ribeiro como uma versão, na nota 10 do artigo Tradução ou adaptação? - a versão de Aquilino Ribeiro, Almeida afirma: "No séc. XX, a tradução incontornável de Aquilino Ribeiro, identificada pela maior liberdade interpretativa" (Almeida, 2006:135). Julio Garcia Morejón também chama a tradução de versão em sua apresentação da obra: "Sempre que Cervantes o permite, Aquilino Ribeiro injeta a mais típica seiva portuguesa na linguagem, acudindo ao riquíssimo veio do povo, à fala viva do povo, 'sempre mais expressiva e a mais pitoresca', como êle afirma. [...] O leitor da versão que aqui se apresenta vai gozar uma das experiências mais arriscadas e originais que se realizaram em Portugal, no campo das traduções, [...], realmente, concretizou-se o fenômeno da nacionalização de uma obra de arte literária, propósito que norteou o tradutor ao iniciar sua empresa" (Morejón, 1963:22-23, itálicos do autor). Ver mais na nota seguinte.

32 "NACIONALIZAR d. Quixote? É isso possível? Há em português traduções várias razoáveis. A pudibundaria de Castilho tolheou-o de ser exato. O culto excessivo do vernáculo prejudicou-lhe também a naturalidade e deslize fluvial que tem o D. Quixote, sem cachopos nem borbotões. De tempos a tempos, empolgado pela ênfase dos pregadores e gongóricos de má morte, dá-nos um Cervantes tire à quatre épingles, arrevesado e pomposo. Benalcanfor está mais perto do original, em despeito das suas insuficiências" (Ribeiro in Cervantes, 1963: 25, negritos e itálicos do autor). Ribeiro usa a palavra "nacionalizar" mais de uma vez, no prefácio da sua autobiografia (nota 18): "É isso que me traz ao proscénio público a expressá-lo, uma vez que adquiri esse direito desde que pretendi nacionalizar, digamos, o engenhoso fidalgo e o escudeiro fiel" (Ribeiro apud Almeida, 2006: 136).
} 
"Traduzir um livro não consiste apenas em vertê-lo para termos equivalentes noutro idioma; é amoldá-lo ao clima e estética dêsse idioma, como se lhes fôsse congênito. [...]" (Ribeiro, 1963: 26). O tradutor também se pergunta sobre suas razões para transpor a obra, "Por que me dei a traduzir D. Quixote? Apenas por isso, o desenfado, a paixão que sempre tive pelo Quixote, me abalancei a cometer a tradução. Não o faria com Shakespeare ou Goethe" (p. 27) ${ }^{33}$. Em 1960 ele é indicado a Prêmio Nobel de Literatura; três anos depois, durante as celebrações do $50^{\circ}$ aniversário do seu primeiro livro, Aquilino Ribeiro adoece e morre aos $78 \operatorname{anos}^{34}$.

No Brasil a sua tradução foi editada pela Difusão Européia do Livro, São Paulo, em 1963 e reeditada uma única vez, em 1967. São dois volumes em capa dura, com introdução de Julio Garcia Morejón ${ }^{35}$. No exemplar informam que as 646 notas são de Maurice Bardon ${ }^{36}$. As quatro únicas ilustrações aparecem em uma lâmina em papel couché antes da página de rosto de cada volume.

\section{A tradução de Eugênio Amado}

Eugênio Amado $^{37}$, o autor exclusivo da segunda tradução brasileira do Quixote, nasceu em Belo Horizonte em 1942, dez anos antes do lançamento da tradução da obra feita por seu pai, Milton Amado. Graduou-se em Geografia e trabalhou como funcionário público. Iniciou realmente sua carreira de tradutor ao encontrar uma tradução inacabada do seu recém-falecido pai, Viagem no interior do Brasil $(1975)^{38}$. Essa tradução foi publicada pela editora Itatiaia (hoje Villa Rica), a mesma com a qual Milton Amado costumava trabalhar e à qual Eugênio Amado ficaria ligado por toda sua vida profissional, inclusive como autor de livros infantis. Traduziu vários livros de

\footnotetext{
${ }^{33}$ Interessante esse comentário. O Visconde de Castilho foi criticado, com é visto mais adiante, exatamente por suas traduções de Shakespeare e Goethe. Outro paradoxo é que, apesar do que diz, Ribeiro traduziu vários autores clássicos.

${ }^{34}$ Portais contendo informações de Aquilino Ribeiro. Disponíveis em: http://www.mundocultural.com.br/index.asp?url=http://www.mundocultural.com.br/literatura1/modernis mo/portugal/aquilino_ribeiro.html e http://sernancelhe.planetaclix.pt/Aquilino-Ribeiro.htm. Acesso em 11 jul. 2009.

${ }_{35} \mathrm{Na}$ época, professor de Língua e Literatura Espanhola na FFLCH/USP.

${ }^{36} \mathrm{Na}$ edição é apresentado como Docteur ès Lettres, Professeur agrégé au Lycée Janson-de-Sailly, autor do prefácio, bibliografia e notas da tradução para o francês de Louis Viardot, intitulada L'ingénieux hidalgo don Quichotte de la Manche. Paris: Garnier Frères, 1850. Não fica esclarecido se a tradução das notas também é de Aquilino Ribeiro.

${ }^{37}$ As informações biográficas foram retiradas de longas conversas telefônicas e uma visita feita a Belo Horizonte para entrevista pessoal, no dia 09 de junho de 2009, na companhia da Professora Dra. Maria Augusta da Costa Vieira (FFLCH/USP).

${ }^{38}$ GARDNER, George. Viagem ao interior do Brasil. Belo Horizonte/São Paulo: Itatiaia/Edusp, 1975.
} 
viagens, duas dessas traduções resultaram em Prêmios Jabuti ${ }^{39}$. Duas grandes obras de Charles Darwin, A origem do homem (1976) e Origem das espécies (1985), também foram traduzidas por ele.

Mesmo com mais de vinte livros traduzidos (inglês, francês e espanhol), o tradutor nunca frequentou escola de idiomas. Contou ter desenvolvido a sua compreensão desses idiomas apenas pelo exercício da leitura. ${ }^{40}$ Eugênio Amado traduziu diversos clássicos da literatura. O primeiro deles foi o Quixote, em 1983. A encomenda partiu do dono da Itatiaia, o mesmo editor, Pedro Paulo Senna Madureira, que havia recomendado Milton Amado para a tradução do Quixote da José Olympio. A edição, com 130 notas, foi um sucesso de vendas, esgotou-se e foi reeditada mais de uma vez, como pode ser observado no catálogo em anexo.

Em 1989 Eugênio Amado traduziu o Livro apócrifo de Dom Quixote de La Mancha, de 1614, assinado por Alonso Avellaneda. Depois de Cervantes, transpôs para o português Fábulas de La Fontaine (1989), mais uma obra iniciada por seu pai, que havia começado a trabalhar com a obra de trás para frente. ${ }^{41}$

A primeira edição do Quixote (1983), assim como as de 1984 e 1991, apresentam-se em dois volumes e 370 ilustrações de Gustave Doré. A introdução de Julio Garcia Morejón é uma revisão do seu texto introdutório feito para a tradução de Aquilino Ribeiro (Difel), com parágrafos inteiros idênticos, diferenciando-se essencialmente na apresentação do tradutor brasileiro.

Às vésperas do quarto centenário da obra, celebrado em 2005, Eugênio Amado recebeu o encargo de revisar sua tradução do Quixote de 1983. Mais de vinte anos haviam se passado, muita coisa mudara, especialmente em relação a tudo que se relaciona com o labor da tradução e a ampliação das possibilidades de pesquisa através de ferramentas eletrônicas. O livro foi lançado em um só volume de capa dura, com as mesmas ilustrações das edições anteriores, inclusive na capa. A introdução é assinada por Lucílio Mariano Júnior, pseudônimo de Eugênio Amado, também autor do prefácio, que contém uma breve biografia de Cervantes e informações históricas da primeira publicação da obra, em 1605.

\footnotetext{
${ }^{39}$ Viagens pelos Rios Amazonas e Negro (1979) de Alfred Russel Wallace e A Força do Conhecimento: a dimensão científica da sociedade (1976) de A. John Ziman, ambos publicados pela Itatiaia/EDUSP.

${ }^{40}$ Ver mais detalhes da entrevista com o tradutor no Anexo, em Cobelo (2009).

${ }^{41}$ A partir daí Eugênio Amado iniciaria uma série de traduções de obras de autores de clássicos infantis, como Irmãos Grimm, Lewis Carroll e Hans Christian Andersen. Parece que a tradução dessas obras para crianças o aproximou da tarefa de escritor; ele tem 22 livros infantis publicados.
} 
O texto foi todo revisado, refinado, as notas quadruplicadas (524 notas), mas o esforço passou despercebido por todos os meios de comunicação: sobre o lançamento da tradução de Eugênio Amado revisada por ele mesmo não se encontrou, durante as pesquisas para este trabalho, sequer uma menção na mídia ${ }^{42}$. Só se ficou sabendo da existência dessa edição após contato pessoal e entrevista com Eugênio Amado, que confirmou o desinteresse da editora em divulgar sua nova tradução. $\mathrm{O}$ tradutor continua vivendo com sua esposa e filha na sua cidade natal de Belo Horizonte.

\section{A tradução de Sérgio Molina}

Segundo as informações nos paratextos das edições do Quixote da Editora 34, Sérgio Molina nasceu no ano de 1964 em Buenos Aires, tendo imigrado para o Brasil com a família aos dez anos de idade e morado algum tempo em Barcelona. O século XXI traz um novo tipo de tradutor. Além de todas as diferenças cibernéticas já mencionadas, segundo Lia Wyler (2003: 140) desde a metade do século passado já começaram a ser formados tradutores na universidade. Responsável pela terceira tradução brasileira do Quixote, lançada em 2002, ele frequentou cursos na USP na área de Ciências Sociais, Letras, Espanhol e Editoração e começou a traduzir em 1986 autores de língua espanhola como Alejo Carpentier, Mario Vargas Llosa, Tomás Eloy, Ricardo Piglia, Beatriz Sarlo e Jorge Luís Borges (Cervantes, 2002: 735). No paratexto sobre o autor encontrado no segundo livro (2007) são citados também Roberto Arlt, Carmen Martín Gaite, Luis Gusmán ${ }^{43}$.

A mídia sobre essa nova tradução do Quixote está completamente ligada ao quarto centenário. O nome de Sérgio Molina aparece em inúmeras entradas em buscas na Internet ${ }^{44}$. A editora expôs e explorou a figura do tradutor, que além de ser uma figura mais valorizada hoje em dia, nesse caso teria cumprido, de maneira simbólica, um pouco o papel de "representante" do escritor, inclusive concedendo a inúmeras entrevistas e participando de palestras e debates sobre a obra na celebração dos seus

\footnotetext{
${ }^{42}$ Essa informação procede do resultado desta investigação. Em breve será feita uma pesquisa sobre essas traduções focando a mídia impressa, mas o próprio tradutor, durante a entrevista, confirmou o desinteresse da editora em divulgar a nova tradução de 2005.

43 No portal da editora Martins Fontes Molina é chamado de "tradutor autodidata". Informam que traduziu cerca de cinquenta títulos do castelhano para o português brasileiro, sobretudo prosa narrativa espanhola e hispano-americana, e que atualmente concilia a atividade de tradução com a de edição. Disponível em: http://www.martinseditora.com.br/detalhes_BiografiaTradutores.asp?id=41. Acesso em 12 jul. 2009.

44 Uma simples busca com o nome do tradutor, Sérgio Molina, mais o nome da obra, Quixote, e selecionando o país Brasil na busca avançada, traz mais de seiscentas entradas no Google (julho 2009).
} 
quatrocentos anos. A maior parte das informações coletadas sobre o processo tradutório de Molina provém da já mencionada entrevista concedida a Dirceu Villa, Ivone Benedetti e Irene Hirsch que foi publicada em Cadernos de Literatura em Tradução 5 (2003).

Trata-se da primeira edição bilíngue brasileira da obra ${ }^{45}$, decisão que Molina atribui unicamente ao editor [Aluízio Leite?], e justifica: "acho que faz sentido oferecer o texto do Quixote em espanhol para aqueles leitores que têm algumas noções do idioma ou até que o lêem fluentemente, que são cada vez mais numerosos" (Villa, Benedetti \& Hirsch, 2003: 165). Molina discorre sobre a opção da estratégia de tradução e como chegou a uma solução intermediária ${ }^{46}$, pois a proposta inicial do editor era fazer "uma versão que privilegiasse o contexto de chegada [...]" (ibid., p.167).

O tradutor do Quixote confessa ter levado certo tempo para descobrir o "atalho", a tradução que proporcionasse ao leitor do século XXI "um texto legível, agradável, gostoso, fluente, com todas as qualidades de uma tradução, sem trair um certo espírito da época, sem falsear demais a linguagem da época" (Villa, Benedetti \& Hirsch, 2003: 168). Para ele as "traduções disponíveis não conseguiam fazer a ponte. [...] não chegavam ao público contemporâneo" (ibid., p.160), e mais adiante explica melhor essa “ponte com o castelhano do século XVII, fazendo-se a triangulação entre o 'brasileiro' contemporâneo, o português clássico e idioma de Cervantes" (ibid., p. 166, aspas dos autores).

Molina explica que só teria conseguido seu objetivo ao "reconhecer as semelhanças entre o nosso português clássico, entender que o ritmo dos textos do século

\footnotetext{
${ }^{45}$ Acredita-se que seja a única em português, mas não foram estudadas aqui todas as edições feitas em Portugal.

${ }^{46}$ O próprio tradutor afirma isso na entrevista: Cadernos (CLT): "Então ou você aborda a tradução a partir dos pressupostos que orientaram a própria obra ou você faz a tua tradução tentando trazer a obra até o leitor, adequando a obra ao leitor. O que você fez? SM: Não fiz nem uma coisa nem outra. Ou as duas juntas. [...] pude intuir que uma tradução equilibrada teria que se mover entre as três estratégias [proposta adaptativa, arcaizante e literalidade]" (Villa, Benedetti e Hirsch, 2003: 167). Porém na contracapa encontra-se um texto que remete ao conceito de estrangeirizar: "Publicado em 1605, D. Quixote chega finalmente à nossa língua numa versão que faz jus à riqueza do original. Esta nova tradução, realizada por Sérgio Molina a partir da mais completa edição crítica da obra, reproduz o ritmo, as modulações e os matizes cômicos característicos de Cervantes, recuperando para o leitor de hoje toda a graça e o encantamento deste que deste que é considerado o primeiro romance moderno" (Cervantes, 2005: contracapa). Mesmo assim, Molina reconhece que: "Existe um limite de estranheza que eu não posso ultrapassar. Tenho que tomar muito cuidado com isso, porque corro o risco de também gerar dificuldades de leitura desnecessárias, sem correspondência com o original" (Villa, Benedetti e Hirsch, 2003: 167). Na opinião dos entrevistadores, o mérito dessa tradução seria sua aproximação com o texto de Cervantes: "[...] maior fidelidade ao original e ao mesmo tempo trazer ao leitor moderno brasileiro alguma coisa que seja bastante compreensível, capaz de levá-lo ao núcleo do Quixote” (ibid., p. 174, itálicos dos autores).
} 
XVII é muito semelhante ao ritmo que a gente imprime à fala brasileira hoje" (ibid., p. 168). Evitou "traços que marcam o português europeu moderno, que não se encontram nos escritos do período clássico" (p. 168). Perguntado sobre como marcou as diferenças dialetais, ele menciona a recriação da fabla, "um dialeto literário, que só existe nas novelas de cavalaria, e que Cervantes faz uma montagem deliberada, que não é a fabla 'pura'. [...]. A linguagem do Sancho também vai se modificando por imitação" (ibid., p. $169)^{47}$.

Discorrendo sobre seu método de trabalho, Molina conta que deixou os poemas para o final, em especial os preliminares, e que foi muito auxiliado pelos revisores, Alexandre Barbosa de Souza e Cide Piquet, a ponto de afirmar que alguns poemas teriam sido "feitos a dois, em inteira colaboração" (ibid., p. 158).

As 382 notas teriam sido embasadas nas notas da edição de partida, organizada por Francisco Rico e editada pelo Instituto Cervantes (Barcelona: Editorial Crítica, $1998)^{48}$ e nas edições organizadas por Martín de Riquer (Barcelona: Círculo de Lectores, 1987) e a francesa de Jean Cannavagio (Paris: La Plêiade, 2002) (Molina in Cervantes, 2002: 731). ${ }^{49}$

O volume, em brochura, tem apenas vinte gravuras de Doré, e conta com um ensaio da Profa. Maria Augusta da Costa Viera (FFLCH/USP), além do Posfácio do Tradutor, uma breve biografia de Cervantes, de Gustave Doré e do tradutor Sérgio Molina $^{50}$. A tradução do primeiro livro foi reeditada em 2003, 2005 e 2007, e a edição de 2008 está esgotada, segundo o portal da editora $34^{51}$. Lá também informam que a “tradução para a primeira parte do Quixote foi premiada na $46^{\circ}$ edição do Prêmio Jabuti [menção honrosa, $3^{\circ}$ lugar], em 2004” (s.p).

O segundo livro foi publicado dois anos após o quarto centenário, em 2007, em brochura, também com texto introdutório pela mesma cervantista brasileira. $\mathrm{O}$ apoio do

\footnotetext{
${ }^{47}$ Ver aqui a observação sobre polilinguismo em Berman (2005:279): "Don Quixote, for example, gathers into itself the plurality of Spanish 'languages' during its epoch, from popular proverbial speech (Sancho) to the conventions of chivalric and pastoral romances. Here the languages are intertwined and mutually ironized" (Berman, 2005:279, aspas e itálicos do autor).

${ }^{48}$ CERVANTES, Miguel de. Don Quijote. Francisco Rico (Ed.). Barcelona: Instituto Cervantes/Editorial Crítica, 1998.

${ }^{49} \mathrm{Na}$ entrevista feita por Dirceu Villa, Ivone Benedetti e Irene Hirsch (2003: 162), Molina informa trabalhar unicamente com o par linguístico espanhol-português, e discorre sobre a elaboração das notas: "eu não fiz essas notas sozinho, pois me baseei nas edições anteriores. [...] A minha contribuição a essa corrente é a seleção, adaptação e mistura de dados".

${ }^{50} \mathrm{E}$ um endereço de e-mail, fazendo uma ponte inédita e muito atualizada entre o tradutor e o leitor. Infelizmente esse recurso foi abolido no segundo livro.

${ }^{51}$ Disponível em: http://www.editora34.com.br . Acesso em 4 jul. 2009.
} 
governo da Espanha é diferente daquele indicado no primeiro livro ${ }^{52}$, como também as edições de referência ${ }^{53}$.

O tradutor confirma receber direitos autorais pelo seu trabalho com o Quixote, graças a um acordo firmado com a editora, uma exceção no mundo editorial.

\section{A tradução de Carlos Nougué e José Luis Sánchez.}

A quarta tradução brasileira foi a primeira feita por uma dupla binacional, visto que Carlos Nougué é brasileiro e José Luis Sánchez nasceu em Barcelona, em 1963. Segundo o portal Lattes ${ }^{54}$, Sánchez é graduado em Tradução e Interpretação, doutor em Filologia Galaico-portuguesa e doutor em Teoria da Tradução pela Universidad Autónoma de Barcelona. Coordena e leciona nos cursos de Pós-Graduação (lato sensu) em Tradução de espanhol e inglês da Universidade Gama Filho ${ }^{55}$. É autor de cinco dicionários de português-espanhol. Traduziu para o espanhol autores como Machado de Assis, José de Alencar, Lima Barreto, Clarice Lispector, Vinicius de Moraes e Lygia Fagundes Telles e possui experiência em tradução técnica e interpretação simultânea.

Em comunicação pessoal, via e-mail, José Luis Sánchez discorreu um pouco sobre a tradução da obra cervantina e o "aval” de instituições espanholas. Segundo ele, a Academia de Letras "lançou uma nova versão [do Quixote], tendo em conta alguns erros de interpretação pela mudança da linguagem em todos esses anos" (Sánchez apud Cobelo, 2009: 140). Essa versão teria conseguido um texto mais compreensível, sem perder o sabor da época, e os tradutores teriam buscado o mesmo na tradução para o português. Ele confirma o aval da "Comissão do IV Centenário, formada por acadêmicos e membros do governo, e o Instituto Cervantes, [...] e que fosse a única tradução avalizada, foi uma grande honra para nós" (ibid.).

Carlos Nougué nasceu no Rio de Janeiro em 1952, viveu dois anos em Montevidéu e hoje vive em Nova Friburgo. Segundo sua biografia disponibilizada no

\footnotetext{
${ }^{52}$ Transcrição da página de verso do rosto: "A presente tradução foi realizada graças ao apoio da Direção Geral do Livro, Arquivos e Bibliotecas do Ministério da Educação, Cultura e Desportos da Espanha" (Cervantes, 2007: 4).

53 "O texto em espanhol de D. Quixote que integra este volume teve por base o estabelecido nas edições de Florêncio Sevilla Arroyo e Antonio Rey Hazas (Alcalá de Henares, Centro de Estúdios Cervantinos, 1993), Martín de Riquer (Barcelona, Planeta, 1997), Francisco Rico (Barcelona, Instituto Cervantes/Galáxia Gutenberg, 2004) e Celina Sabor de Cortázar e Isaías Lerner (Buenos Aires, Eudeba, 2005) - cotejadas com a edição princeps de 1615 -, refletindo as opções do tradutor em face das diversas variantes adotadas em cada uma delas" (Cervantes, 2007:27, itálicos no original).

${ }^{54}$ Disponível em: http://buscatextual.cnpq.br/buscatextual/visualizacv.jsp?id=T221239. Acesso em 13 jul. 2009.

55 Disponível em: http://www.traduespanhol.info/. Acesso em 02 jul. 2010.
} 
$D_{\text {Ditra }}{ }^{56}$, ele "estudou Filosofia na Escola Teológica do Mosteiro de São Bento" (2005: s.p.) e é professor de Língua Portuguesa e Filosofia Medieval. Em 1988 teria começado a traduzir textos do espanhol, latim, francês e inglês. Recebeu o Prêmio Jabuti em 1993 por sua tradução de Cristóvão Nonato, de Carlos Fuentes. Sobre sua produção como tradutor, existem divergências nas informações. O Ditra menciona um número ao redor de 40 obras e a organização de dois livros. Em sua entrevista ele afirma: "alguém que viveu quase toda a vida de tradução, com mais de 400 traduções em cerca de 30 anos..." (Nougué apud Cobelo, 2009: 243). Antes da tradução de Cervantes, havia trabalhado com clássicos como Quevedo, Miguel Hernández, Cícero, Sêneca, Santo Agostinho e Balzac.

O primeiro livro do Quixote foi publicado pela editora Record em 2005. É uma edição brochura, sem ilustrações e com uma breve apresentação assinada por Francisco Corral, diretor do Instituto Cervantes-RJ ${ }^{57}$. O tradutor Carlos Nougué explica como foi o processo tradutório: ele, por ser brasileiro, fez o primeiro esboço, "num português à Gil Vicente, Camões e Padre Antônio Vieira, além de traduzir poeticamente os poemas" (Nougué apud Cobelo, 2009: 138). Sánchez, que é espanhol, não só revisou como corrigiu o sentido, baseando-se nas muitas edições críticas da obra de Cervantes. Segundo Nougué, o fato mais curioso foi terem feito a tradução vivendo ele no Uruguai e Sánchez na Espanha, e sem maiores problemas, "nada que Internet e telefone não pudessem resolver" (Ibid.).

Em várias referências, inclusive no portal da editora Record ${ }^{58}$, aparece a informação de que essa tradução seria a "primeira tradução para o português avalizada pelo Instituto Cervantes e pela Comissão IV do Quarto Centenário, criada em 2005 pelo Governo da Espanha para comemorar quatrocentos anos da publicação da primeira parte do Quixote ${ }^{, 59}$. Nas referências ${ }^{60}$ sempre aparecem trechos da Nota dos Tradutores, texto

\footnotetext{
${ }^{56}$ Disponível em: http://www.dicionariodetradutores.ufsc.br/pt/CarlosNougue.htm. Acesso em 13 jul. 2009.

${ }^{57}$ Transcrição do trecho final: "Uma nova tradução supõe sempre um novo desafio, pois nasce coma a responsabilidade de ter que superar todas as anteriores em qualidade e em precisão. Neste caso, o fato de ter sido realizada em equipe por dois respeitados tradutores, um brasileiro e um espanhol (Carlos Nougué e José Luis Sánchez), constitui a melhor garantia e o melhor augúrio para predizer que traduzirá ao belo acento brasileiro da língua de Camões toda a enorme riqueza de matizes, sentidos, sugestões, contrasensos, intenções e segundas intenções que Miguel de Cervantes logrou conceber e plasmar nesta obraprima da literatura universal" (Corral in Cervantes 2005:12).

${ }_{58}^{58}$ Disponível em: http://www.record.com.br/livro_sinopse.asp?id_livro=19278. Acesso em 13 jul. 2009.

${ }^{59} \mathrm{O}$ portal Observatório Literário chama a tradução da Record de "primeira tradução oficial para o português" e mencionam o mesmo press release sobre o aval do Instituto Cervantes/Comissão IV centenário. O título da resenha é: "Brasil ganha tradução oficial de D. Quixote". Disponível em: http://www.bestiario.com.br/observatorio/livros_jorge de dom_quixote.html. Acesso em: 3 dez. 2008.
} 
introdutório da edição, assinado por Nougué e Sánchez, no qual discutem suas dificuldades e opções tradutórias ${ }^{61}$, como manter as inversões sintáticas do estilo de Cervantes, assim como tudo que "morfológica e sintaticamente fosse igual comum ao espanhol e ao português de então [...]” (Nougué \& Sánchez, 2005:15). Os tradutores explicam que só utilizaram palavras que surgiram no português até o século XVII. Os editores esclarecem em nota, que as 41 notas de rodapé foram feitas pelos tradutores, embasados tanto nas notas do Instituto Cervantes, como na edição do Quijote pela Real Academia Española e pela editora Alfaguara, em 2004. A tradução de Nougué e Sánchez também obteve atenção da mídia; aparece em vários $\operatorname{artigos}^{62}$, embora não tanto como a edição da Editora 34, sendo alvo de bastante divulgação não só durante as celebrações do quarto centenário da primeira edição da obra, como também em eventos como a 19ª Bienal Internacional do Livro de São Paulo, em 2006. Nesse mesmo ano, a tradução foi finalista do Prêmio Jabuti. Na sua entrevista, Nougué anunciou o lançamento da tradução do segundo livro para o final de 2009, mas até julho de 2010 a previsão não havia sido confirmada.

\section{As edições do Quixote publicadas no Brasil}

Foi feito um estudo historiográfico das edições da obra no país, desde a primeira — a tradução portuguesa feita pelos Viscondes e Chagas, publicada em 1942/43 — até a mais recente tradução bilíngue feita por Sergio Molina em 2005, com reimpressão em 2008. Foram recolhidos dados como ano de publicação, editora responsável, tradutor(es), número de páginas, existência e autoria de ilustrações, assim como a existência de paratextos. Essas informações foram resumidas na forma de um catálogo, que é apresentado a seguir. Também foi elaborada uma tabela com as edições e reimpressões do Quixote e comparadas as percentagens de edições por tradutor.

\footnotetext{
${ }^{60}$ NOVA TRADUÇÃO... (2008), SOUZA (2006), O ENGENHOSO... (2008), assim como em publicações jornalísticas, como a revista Veja, publicado 18 jan. 2006. Disponível em: http://veja.abril.com.br/180106/veja_recomenda.html. Acesso em 29 jan. 2009.

${ }^{61}$ Fragmento do texto: "Em que português verter o Quixote? Pô-lo em português moderno não seria propriamente traduzir, mas adaptar. Não era essa nossa proposta. Pretendíamos traduzi-lo resolvendo uma como 'equação de três incógnitas': como escreveria Cervantes o Quixote no português de sua época, mas sem perder o sabor hispânico de então e, ainda, de modo compreensível para o leitor de hoje?" (Nougué e Sánchez, Cervantes, 2005:13, itálico dos autores). Notar as semelhanças com o discurso de Molina, em especial na entrevista ao CLT, que diz que manterá as construções sintáticas no segundo livro mesmo que pareçam espanholizantes, algo que soaria como os escritos do português clássico (Villa, Benedetti e Hirsch, 2003:173).

${ }^{62}$ Fazendo uma busca no Google (13 jul. 2009) com o nome do tradutor entre aspas + Quixote, selecionando idioma português: Carlos Nougué, 138 entradas, José Luis Sánchez, 112.
} 
Catálogo das traduções do Quixote publicadas no Brasil ${ }^{63}$

\begin{tabular}{|c|c|c|c|c|}
\hline Ano & Editora & Tradutor & Descrição & Páginas \\
\hline 1942 & Edições Cultura & $\begin{array}{l}\text { Viscondes / } \\
\text { Chagas }\end{array}$ & Pref.: José Pérez - Vol. I - Ilustrações: Tarsila do Amaral & 586 \\
\hline 1943 & Edições Cultura & $\begin{array}{l}\text { Viscondes / } \\
\text { Chagas }\end{array}$ & Pref.: José Pérez - Intr.: Luis Amador Sánchez - Vol. II & 614 \\
\hline 1945 & Edições Cultura & $\begin{array}{l}\text { Viscondes / } \\
\text { Chagas }\end{array}$ & Reimpressão - Dois Vol. & 614 \\
\hline 1948 & W.M.Jackson & $\begin{array}{l}\text { Viscondes / } \\
\text { Chagas }\end{array}$ & Pref.: Federico de Onís - Dois Vol. & $465 \mathrm{~cd}$ \\
\hline 1949 & W.M.Jackson & $\begin{array}{l}\text { Viscondes / } \\
\text { Chagas }\end{array}$ & Reimpressão & \\
\hline 1952 & José Olympio & $\begin{array}{l}\text { Andrade e } \\
\text { Amado }\end{array}$ & $\begin{array}{c}\text { Pref.: Luís da Câmara Cascudo - Intr.: José Brito Broca - } \\
\text { Ilustr.: Gustave Doré - Cinco Vol. }\end{array}$ & 1864 \\
\hline 1952 & W.M.Jackson & $\begin{array}{l}\text { Viscondes / } \\
\text { Chagas }\end{array}$ & (2) & 1864 \\
\hline 1954 & José Olympio & $\begin{array}{l}\text { Andrade e } \\
\text { Amado }\end{array}$ & Tradução revisada e acréscimo de NT. por Milton Amado & \\
\hline 1955 & Atena & $\begin{array}{l}\text { Viscondes / } \\
\text { Chagas }\end{array}$ & Pref.: Luis Amador Sánchez - Dois Vol. & \\
\hline 1955 & Logos & $\begin{array}{l}\text { Viscondes / } \\
\text { Chagas }\end{array}$ & Ilustrações: Gustave Doré - Dois Vol. & \\
\hline 1955 & Tietê & $\begin{array}{l}\text { Viscondes / } \\
\text { Chagas }\end{array}$ & $\begin{array}{l}\text { Comentários e NT.: Artur Neves - Ilustr.: Gustave Doré } \\
\text { (356) e outros - Quatro Vol. }\end{array}$ & 201 (vol.1) \\
\hline 1956 & W.M.Jackson & $\begin{array}{l}\text { Viscondes / } \\
\text { Chagas }\end{array}$ & Reimpressão & \\
\hline 1957 & Edigraf & $\begin{array}{l}\text { Viscondes / } \\
\text { Chagas }\end{array}$ & Ilustr.: Gustave Doré - Três Vol. & \\
\hline 1957 & Logos & $\begin{array}{l}\text { Viscondes / } \\
\text { Chagas }\end{array}$ & Reimpressão - Três Vol. - Ilustrações : Gustavo Doré & 1226 \\
\hline 1958 & José Olympio & $\begin{array}{l}\text { Andrade e } \\
\text { Amado }\end{array}$ & Reimpressão e acréscimos de NT. por Milton Amado & 1854 \\
\hline 1958 & Circulo do Livro & $\begin{array}{l}\text { Andrade e } \\
\text { Amado }\end{array}$ & Prefácio Otto Maria Carpeaux - Ilustrações Gerhat Kraaz & \\
\hline 1960 & Edigraf & $\begin{array}{l}\text { Viscondes / } \\
\text { Chagas }\end{array}$ & Reimpressão & \\
\hline 1960 & José Aguilar & $\begin{array}{l}\text { Viscondes / } \\
\text { Chagas }\end{array}$ & $\begin{array}{l}\text { Textos: Julio Cejador y Frauca, Justo García Soriano, Justo } \\
\text { García Morales - Vol. Único }\end{array}$ & 1150 \\
\hline 1960 & W.M.Jackson & $\begin{array}{c}\text { Viscondes / } \\
\text { Chagas }\end{array}$ & Reimpressão & \\
\hline 1963 & $\begin{array}{c}\text { Difusão Européia } \\
\text { do Livro }\end{array}$ & Aquilino Ribeiro & $\begin{array}{c}\text { Intr.: Julio García Morejón - Pref.: Aquilino Ribeiro - NT. } \\
\text { Maurice Bardon - Dois Vol. } \\
\end{array}$ & $466 / 473$ \\
\hline 1964 & W.M.Jackson & $\begin{array}{l}\text { Viscondes / } \\
\text { Chagas }\end{array}$ & Reimpressão & \\
\hline 1967 & $\begin{array}{c}\text { Difusão Européia } \\
\text { do Livro }\end{array}$ & Aquilino Ribeiro & Reimpressão & \\
\hline 1970 & W.M.Jackson & $\begin{array}{l}\text { Viscondes / } \\
\text { Chagas }\end{array}$ & Reimpressão & \\
\hline 1973 & José Olympio & $\begin{array}{l}\text { Andrade e } \\
\text { Amado }\end{array}$ & Reimpressão & \\
\hline 1975 & Abril Cultural & $\begin{array}{l}\text { Viscondes / } \\
\text { Chagas }\end{array}$ & $\begin{array}{c}\text { Vol. Único - NT. José Maria Castro Calvo traduzidas por } \\
\text { Fernando Nuno Rodrigues }\end{array}$ & 609 \\
\hline 1978 & Abril Cultural & $\begin{array}{l}\text { Viscondes / } \\
\text { Chagas }\end{array}$ & Reimpressão & \\
\hline 1978 & Círculo do Livro & $\begin{array}{l}\text { Viscondes / } \\
\text { Chagas }\end{array}$ & $\begin{array}{c}\text { Intr.:Otto Maria Carpeaux - Ilustr.: Gerhat Kraaz - Vol. } \\
\text { Único - NT.: Castro Calvo/Rodrigues }\end{array}$ & 863 \\
\hline 1980 & Círculo do Livro & $\begin{array}{l}\text { Viscondes / } \\
\text { Chagas }\end{array}$ & Reimpressão & \\
\hline 1980 & Otto Pierre & $\begin{array}{c}\text { Viscondes / } \\
\text { Chagas } \\
\end{array}$ & Ilustr.: Gustave Doré - Dois Vol. & $310 / 352$ \\
\hline 1981 & Abril Cultural & $\begin{array}{l}\text { Viscondes / } \\
\text { Chagas } \\
\end{array}$ & Reimpressão & \\
\hline
\end{tabular}

${ }^{63}$ Abreviações: Intr.: Introdução, Pref.: Prefácio, Vol.: Volume, NT: Notas de rodapé, 


\begin{tabular}{|c|c|c|c|c|}
\hline 1981 & Círculo do Livro & $\begin{array}{l}\text { Viscondes / } \\
\text { Chagas }\end{array}$ & Reimpressão & \\
\hline 1981 & Abril Cultural & $\begin{array}{l}\text { Viscondes / } \\
\text { Chagas }\end{array}$ & $\begin{array}{c}\text { NT José Maria Castro Calvo traduzidas por Fernando Nuno } \\
\text { Rodrigues }\end{array}$ & \\
\hline 1983 & Círculo do Livro & $\begin{array}{l}\text { Viscondes / } \\
\text { Chagas }\end{array}$ & Reimpressão - Dois Vol. & $440 / 422$ \\
\hline 1983 & $\begin{array}{c}\text { Civilização } \\
\text { Brasileira }\end{array}$ & $\begin{array}{l}\text { Viscondes / } \\
\text { Chagas }\end{array}$ & $\begin{array}{c}\text { Intr.:Otto Maria Carpeaux - Ilustr.: Gerhat Kraaz - Vol. } \\
\text { Único - NT.: Castro Calvo/Rodrigues }\end{array}$ & 863 \\
\hline 1983 & Itatiaia & Eugênio Amado & $\begin{array}{l}\text { Intr. : Julio García Morejón - Ilustr.: Gustavo Doré (370) - } \\
\text { Dois Vol. }\end{array}$ & $491 / 531$ \\
\hline 1984 & Cultura Universal & $\begin{array}{c}\text { Viscondes / } \\
\text { Chagas }\end{array}$ & Pref.: Federico de Onís - Dois Vol. & \\
\hline 1984 & Itatiaia & Eugênio Amado & Reimpressão & \\
\hline 1987 & Círculo do Livro & $\begin{array}{l}\text { Viscondes / } \\
\text { Chagas }\end{array}$ & Reimpressão & \\
\hline 1990 & Nova Cultural & $\begin{array}{l}\text { Viscondes / } \\
\text { Chagas }\end{array}$ & Reimpressão & 609 \\
\hline 1990 & Circulo do Livro & $\begin{array}{l}\text { Viscondes / } \\
\text { Chagas }\end{array}$ & Reimpressão & \\
\hline 1991 & Villa Rica & Eugênio Amado & Reimpressão & \\
\hline 1992 & Círculo do Livro & $\begin{array}{l}\text { Viscondes / } \\
\text { Chagas }\end{array}$ & Reimpressão & \\
\hline 1993 & Círculo do Livro & $\begin{array}{l}\text { Viscondes / } \\
\text { Chagas }\end{array}$ & Reimpressão & \\
\hline 1993 & Nova Aguilar & $\begin{array}{l}\text { Viscondes / } \\
\text { Chagas }\end{array}$ & Reimpressão & \\
\hline 1993 & Nova Cultural & $\begin{array}{l}\text { Viscondes / } \\
\text { Chagas }\end{array}$ & Reimpressão & \\
\hline 1995 & Nova Cultural & $\begin{array}{l}\text { Viscondes / } \\
\text { Chagas }\end{array}$ & Reimpressão & \\
\hline 1997 & Villa Rica & Eugênio Amado & Reimpressão & \\
\hline 1998 & Nova Cultural & $\begin{array}{l}\text { Viscondes / } \\
\text { Chagas }\end{array}$ & Reimpressão & \\
\hline 1998 & Ediouro & $\begin{array}{l}\text { Andrade e } \\
\text { Amado }\end{array}$ & Intr.: Brito Broca - Dois Vol. & $556 / 651$ \\
\hline 1998 & Publifolha/Ediouro & $\begin{array}{l}\text { Andrade e } \\
\text { Amado }\end{array}$ & Intr.: Brito Broca - Dois Vol. & $560 / 556$ \\
\hline 2002 & Ediouro & $\begin{array}{l}\text { Andrade e } \\
\text { Amado }\end{array}$ & Intr.: Brito Broca - Ilustrações: Gustave Doré - Três Vol. & $678 / 679 / 467$ \\
\hline 2002 & Editora 34 & Sergio Molina & $\begin{array}{c}\text { Apresentação: Maria Augusta da Costa Vieira - Ilustr.: } \\
\text { Gustave Doré (20) - } 1^{\circ} \text { Livro } \\
\end{array}$ & 736 \\
\hline 2002 & Nova Cultural & $\begin{array}{c}\text { Viscondes / } \\
\text { Chagas }\end{array}$ & Reimpressão & 690 \\
\hline 2003 & Editora Pradense & $\begin{array}{l}\text { Viscondes / } \\
\text { Chagas }\end{array}$ & Intr.: Ricardo Stefani - Vol. Único & \\
\hline 2003 & Editora 34 & Sergio Molina & Reimpressão - Primeiro Livro & \\
\hline 2003 & Nova Cultural & $\begin{array}{l}\text { Viscondes / } \\
\text { Chagas }\end{array}$ & Reimpressão & 690 \\
\hline 2004 & Ediouro & $\begin{array}{l}\text { Andrade e } \\
\text { Amado }\end{array}$ & Reimpressão & \\
\hline 2004 & Nova Aguilar & $\begin{array}{l}\text { Viscondes / } \\
\text { Chagas }\end{array}$ & Reimpressão & \\
\hline 2005 & Ediouro & $\begin{array}{l}\text { Andrade e } \\
\text { Amado }\end{array}$ & Reimpressão & \\
\hline 2005 & Editora 34 & Sergio Molina & $\begin{array}{c}\text { Primeira Parte Apresentação: Maria Augusta da Costa } \\
\text { Vieira - Ilustr.: Gustave Doré }\end{array}$ & 736 \\
\hline 2005 & Martin Claret & $\begin{array}{l}\text { Viscondes / } \\
\text { Chagas }\end{array}$ & Ilustr.: Gustave Doré - Dois Vol. & $592 / 624$ \\
\hline 2005 & Record & $\begin{array}{l}\text { Nougué e } \\
\text { Sánchez }\end{array}$ & $\begin{array}{c}\text { Apresentação: Francisco Corral - NT. dos tradutores: } \\
\text { Nougué e Sánchez }-1^{\circ} \text { Livro }\end{array}$ & 570 \\
\hline 2005 & L \& PM & $\begin{array}{l}\text { Viscondes / } \\
\text { Chagas }\end{array}$ & $\begin{array}{l}\text { Notas traduzidas por Fernando Nunos Rodrigues - Dois } \\
\text { Vol. }\end{array}$ & $511 / 518$ \\
\hline 2005 & Villa Rica & Eugênio Amado & $\begin{array}{c}\text { Tradução revisada - Intr.: / Pref.: Eugênio Amado - Ilustr.: } \\
\text { Gustave Doré - Vol. Único } \\
\end{array}$ & 994 \\
\hline
\end{tabular}




\begin{tabular}{|c|c|c|c|c|}
2 & Viscondes / & Reimpressão & 736 \\
\hline 2006 & L \& PM & $\begin{array}{c}\text { Chagas } \\
\text { Viscondes / } \\
\text { Chagas }\end{array}$ & $\begin{array}{c}\text { Nota do Editor: Teotonio Simões - Texto: Rudolf Rocker - } \\
\text { Dois Vol. }\end{array}$ & $919 / ?$ \\
\hline 2007 & Editora 34 & Sergio Molina & $\begin{array}{c}\text { Segunda Parte Apresentação Maria Augusta da Costa Vieira } \\
\text { e- Ilustr.: Gustave Doré }\end{array}$ & 856 \\
\hline 2007 & Editora 34 & Sergio Molina & Reimpressão - Primeiro Livro & 736 \\
\hline 2007 & Martin Claret & $\begin{array}{c}\text { Viscondes / } \\
\text { Chagas }\end{array}$ & Reimpressão & $592 / 624$ \\
\hline 2007 & L \& PM & $\begin{array}{c}\text { Viscondes / } \\
\text { Chagas }\end{array}$ & Reimpressão & $511 / 518$ \\
\hline 2008 & Martin Claret & $\begin{array}{c}\text { Viscondes / } \\
\text { Chagas }\end{array}$ & Reimpressão & $592 / 624$ \\
\hline 2008 & Editora 34 & Sergio Molina & Reimpressão - Primeiro Livro & 736 \\
\hline
\end{tabular}

\section{Participação por tradutor(es) nas várias edições em português}

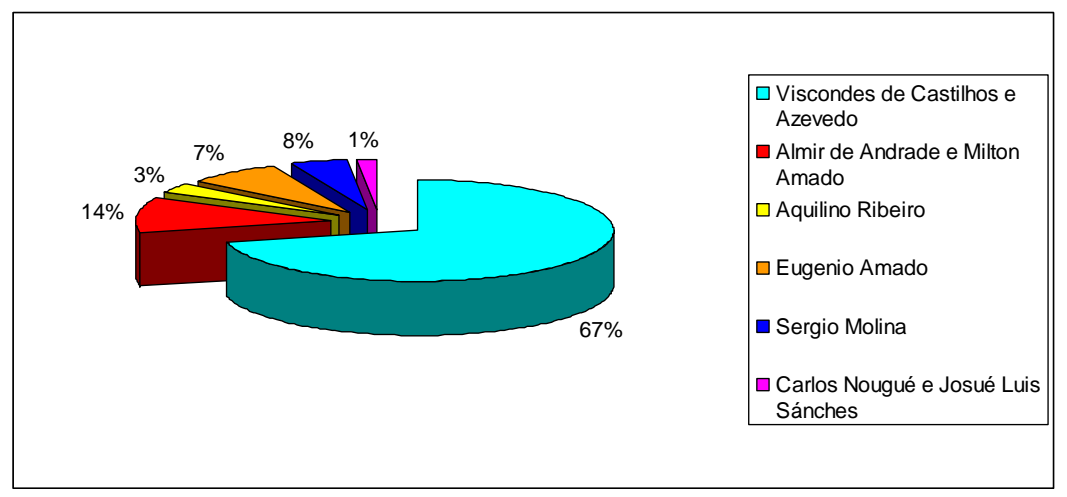

Das 72 edições, a tradução Visconde/Chagas, editada 48 vezes, corresponde a $67 \%$ do total, um número muito alto, considerando que a tradução portuguesa do século XIX só aparece em cinco edições antes da primeira tradução brasileira publicada pela José Olympio, em 1952. Nesse caso fica evidente a opção, mais econômica, por uma tradução que não exige pagamento de direitos autorais a tradutores ou editores. Cria-se uma situação paradoxal na qual, mesmo existindo traduções mais próximas ao universo contemporâneo do leitor, este, muitas vezes, é obrigado a ler a obra em uma versão de dois séculos atrás, escrita em português de Portugal, especialmente se depender de uma biblioteca pública ${ }^{64}$.

\footnotetext{
${ }^{64}$ Pelas pesquisas feitas, a tradução Viscondes/Chagas é a mais encontrada nas bibliotecas públicas - a edição de 2002 da Nova Cultural é a que mais aparece, foi adquirida em 41 bibliotecas do CEU e três outras bibliotecas públicas - seguida por algumas edições da tradução da José Olympio. Não foi encontrada nenhuma tradução do século XXI em bibliotecas públicas de São Paulo (exceção para a biblioteca da FFLCH/USP, com exemplares conseguidos pela Profa. Maria Augusta da Costa Vieira e pelo Programa de Língua Espanhola e Literatura Espanhola e Hispano-americana), nem na Biblioteca Nacional. Conferir em: http://www.prefeitura.sp.gov.br/cidade/secretarias/cultura/bma/sobre biblioteca e http://catalogos.bn.br. Acesso em 08 maio 2009.
} 
Em segundo lugar, bem afastada, está a primeira tradução brasileira, de Andrade/Amado, com dez edições (14\%). A tradução de Eugênio Amado contribui com cinco edições $(7 \%)$, menos que a tradução contemporânea bilíngue de Molina, com participação de $8 \%$, e se considerarmos que a primeira edição dessa versão é recente, parece estar crescendo rápido e certamente modificará esse panorama dentro de alguns anos.

A tradução de Nougué/Sánchez, a única feita por profissionais com graduação e atuação acadêmica em tradução, tem a porcentagem prejudicada por ter sido editada uma única vez e por não ter saído ainda a tradução do segundo livro. No portal da editora, agora denominada Grupo Editorial Record ${ }^{65}$, são informados seus nove selos. Muitos deles eram antigas editoras/selos incorporados, e em seus catálogos estão três diferentes traduções do Quixote, Andrade/Amado, da José Olympio, a de Aquilino Ribeiro, da Difel e a Viscondes/Chagas, editada pela Civilização Brasileira. Mesmo tendo direito de lançar alguma tradução lançada por alguma de esses seus selos, a editora preferiu encomendar uma tradução nova, demonstrando uma nova atitude editorial quanto à importância de uma nova tradução de uma obra canônica mesmo na existência de outras, inclusive contemporâneas.

\section{Quadro comparativo das seis traduções e o texto de Cervantes}

Para dar apenas um exemplo das diferenças entre as traduções, coteja-se um trecho do capítulo XV do primeiro livro do Quixote, em um dos momentos em que Sancho Pança encadeia um provérbio atrás do outro, como numa "avalanche", artifício utilizado, com essa intensidade, em sete capítulos da obra. As notas de rodapé foram transcritas e incluídas nas notas deste artigo.

- Ni yo lo digo ni lo pienso - respondió Sancho -. Allá se lo hayan, con su
pan se lo coman: ${ }^{66}$ si fueron amancebados o no, a Dios habrán dados la
cuenta. De mis vinas vengo, no sé nada, ${ }^{67}$ no soy amigo de saber vidas
ajenas, que el que compra y miente, en su bolsa lo siente. Cuanto más, que
desnudo nací, desnudo me hallo: ni pierdo ni gano. ${ }^{68}$ Mas que lo fuesen

\footnotetext{
${ }^{65}$ Disponível em: http://www.record.com.br/. Acessado em 07 jul. 2009.

${ }^{66}$ Nota Rico: "Todo el parlamento de Sancho es una retahíla de refranes, cuyo significado es 'A mí qué más me da"'. (Cervantes, 2004:233, aspas do autor).

${ }^{67}$ Nota Rico: "Provérbio que indica que alguien se desentiende o no le importa lo que pasa; parece provenir de algún cuentecillo. El discurso entero de Sancho es una sarta de refranes, en la que todos vienen a significar lo que se dice al cerrarla: ¿qué se me da a mí?" (Cervantes, 2001: 273).

${ }^{68}$ Nota Rico: "Sancho vuelve a repetir ese refrán de reminiscencias bíblicas varias veces en la Segunda parte" (Cervantes 2001:273).
} 
¿qué me va a mí? Y muchos piensan que hay tocinos, $y$ no hay estacas. ${ }^{69}$ Mas ¿quién puede poner puertas al campo? ${ }^{70}$ Cuanto más que de Dios dijeron $^{71}$

- ¡Válame Dios - dijo don Quijote - y qué de necedades vas, Sancho,

ensartando! ¿Qué va de lo que tratamos a los refranes que enhilas?

(Cervantes, 2001: 273; 2004: 233)

Nem eu o digo, nem tal cuido, respondeo Sancho; lá se hajaõ elles; com paõ o comã̃; se andarão, ou naõ mal encaminhados, a Deos teraõ dado conta: que eu das minhas vinha venho, e naõ sei nada; taõ pouco sou amigo de saber das vidas alheias; que quem compra, e mente na bolça o sente: e demais disso, se nu nasci, nu aqui me acho, nem perco, nem ganho; e quando o andassem, que me dá a mim disso? Muitos há que cuidaõ que ha de pôr portas ao campo? Muitos mais disseraõ de Deos. Valhame Deos, disse D. Quixote, que sandices vais ahi enfiando: que tem o que estamos tratando, meu Sancho, com os proverbios com que vens? (Cervantes, tradução anônima, 1794: 46)

- Eu cá não o profiro nem o penso - respondeu Sancho -, os outros lá se avenham; e se maus caldos mexerem, tais os bebam. Se foram amancebados ou não, contas são essas que já dariam a Deus; não sei nada $^{72}$, das minhas vinhas venho. Que me importam vidas alheias? Quem compra e mente na bolsa o sente; quanto mais, que nu vim ao mundo, e nu me vejo; nem perco nem ganho. E também que o fossem, que me faz isso a mim? Há muitos que pensam encontrar toicinhos e não há nem estacas; mas quem pode ter mão em línguas de praguentos, se nem Cristo se livrou delas?

- Valha-me Deus! - disse Dom Quixote. - Que de tolices vais enfiando, Sancho! que tem que ver o nosso caso com os adágios que estás arreatando? (Cervantes, tradução Viscondes/Chagas, 1987: 139)

- Eu não digo, nem penso - respondeu Sancho; - êles que lá se avenham e com as usas linhas se cosam; pouco se me dá se foram amancebados, ou não; prestarão contas a Deus. Venho das minhas vinhas, de nada sei; não sou amigo de farejar vidas alheias, pois quem compra e mente, na sua bôlsa o sente. Tanto mais que nasci nu e nu me encontro; não perco, nem ganho. Também, se o fôssem, que me importaria a mim? Muitos pensam que há toicinhos onde só há espetos. $\mathbf{E}$ quem pode pôr cobro às más línguas, depois do que disseram do próprio Deus?

- Valha-me Nosso Senhor! - exclamou Dom Quixote. - Quantas tolices vais aí desfiando, Sancho! Que tem que ver o de que tratamos com os refrãos que numeras? (Cervantes, tradução Andrade/Amado, 1958:397-398)

\footnotetext{
${ }^{69}$ Nota Rico: "Refrán: 'muchos suponen algo de alguien sin ningún fundamento'; tocinos: hojas de la canal del cerdo', que se salaban y se conservaban colgadas de estacas clavadas en la pared" (2001: 273 aspas e itálicos do autor).

“"las apariencias engañan'; el dicho tiene su origen em la costumbre de colgar de unas estacas las piezas de tocino salado" (Cervantes, 2004: 233, aspas do autor).

${ }^{70}$ Nota Rico: ““quién puede poner límites a la libertad?’” (Cervantes, 2001 e 2004, aspas do autor).

${ }^{71}$ Nota Rico: "La frase proverbial es "Déjalos que digan, que aun de Dios dijeron", para despreciar al maldiciente o a las maledicencia; digan: 'murmuren"” (Cervantes, 2001: 273, aspas e itálicos do autor). 'que incluso de Dios murmuraron'. La acumulación de refranes que siempre se recuerda como característica de Sancho aparece aquí por primera vez, "pero este primer chorreo queda aislado, y Cervantes ya no volverá a él hasta la Segunda parte (Fernando Lázaro Carreter, in Cervantes 2004: 233)

${ }^{72}$ Nota Viscondes/Chagas: "Para escusar-se do mal feito" (Cervantes, 178: 139).
} 
- Eu cá não digo nem penso nada - acudiu Sancho. - Lá se avenham. Sua alma, sua palma. Se se porquearam juntos, a Deus terão de dar contas. Não gosto de meter o nariz na vida alheia. Quem compra e mente, na bôlsa o sente. Olhe, meu senhor, por mim tanto se me dá como se me deu. Onde elas se fazem, lá se pagam. Que fôssem amigos, que tenho eu lá com isso?! Não há dúvida, quase sempre são mais as vozes que as nozes. Quem pode calar as bôcas do mundo?! Pois não disseram mal de Cristo e mais era Deus?!

- Santo Breve da marca - exclamou D. Quixote - para asneiras és um barra! De todo chorrilho de rifões nenhum acertou a carapuça (Cervantes, tradução Ribeiro, 1963: 214).

- Tal coisa eu não digo nem penso - respondeu Sancho; - eles que por lá se avenham, e que cada qual coma do seu próprio pão; se foram amancebados ou não, contas a Deus prestarão. De minhas vinhas cheguei, e de nada sei; não sou amigo de me intrometer nas vidas alheias, pois quem compra e mente, na sua bolsa é que sente. Tanto mais que pelado nasci e pelado me encontro; não perco nem ganho. De mais, se o fossem, a mim que me importa? Muitos pensam que há toicinho onde não existe espeto. E quem pode colocar porteiras no campo? Tanto mais, que até ao próprio Deus difamaram...

- Valha-me Deus! - exclamou Dom Quixote.- Quantos disparates vais aí desfiando, Sancho! Que tem a ver o que tratamos com os refrãos que desembuchas? (Cervantes, tradução Eugênio Amado, 1991: 220221)

- Tal coisa eu não digo nem penso - respondeu Sancho; - eles que por lá se avenham, e que cada qual coma do seu próprio pão. Se foram amancebados ou não, contas a Deus prestarão. De minhas vinhas venho e de nada sei; não sou amigo de me intrometer nas vidas alheias, pois quem compra e mente, na sua bolsa é que sente. Tanto mais que pelado nasci e pelado me encontro; não perco nem ganho; de mais, se o fossem, a mim que me importa? Muitos pensam que há toicinho onde nem espeto existe. $\mathbf{E}$ quem pode colocar porteiras no campo? Tanto mais, que até do próprio Deus andaram falando mal...

- Valha-me Deus! - exclamou dom Quixote. - Quantos disparates vais aí desfilando, Sancho! Que tem a ver o que tratamos com os refrãos que encadeias? (Cervantes, tradução Eugênio Amado, 2005:229-231)

- Eu aqui não digo nem penso - respondeu Sancho. - Eles lá que se amanhem e colham sua semeadura: se viveram ou não amancebados, a Deus que prestem contas. Eu sigo meu trilho, não sei de nada nem sou amigo de saber as vidas alheias, pois quem compra e mente, na bolsa o sente. Quanto mais, que nu nasci e nu estou: não perco nem ganho. E se eles acaso o fossem, que teria eu com isso? Pois às vezes são mais as vozes que as nozes. Mas quem pode pôr rédeas ao vento? Quanto mais, que até Deus foi malfalado.

- Valha-me Deus, Sancho - disse D. Quixote -, que fieira de necedades! Que tem que ver o que tratamos com os ditados que desfias? (Cervantes, tradução Sérgio Molina, 2005: 325)

- Eu cá não digo nem penso - respondeu Sancho. - Eles lá que saibam as linhas com que se cosem, ${ }^{73}$ pouco se me dá: se foram amancebados ou não, a Deus terão prestado contas. Eu sigo o meu caminho, não sei de nada, não sou amigo de me meter na vida alheia, pois quem mexe em vespeiro, picado sairá. Tanto mais que nu nasci, nu estou:_não perco nem ganho. Mas, se o eram, que me importa a mim? E nem tudo o que reluz é ouro. Mas quem pode pôr travas ao vento? Tanto mais que até de Deus murmuraram. ${ }^{74}$

- Valha-me Deus - disse D. Quixote -, que de necedades, Sancho, estás enfiando! Que tem que ver o que tratamos com os provérbios que estás desfiando? (Cervantes, tradução Nougué/Sánchez, 2005: 260)

\footnotetext{
${ }^{73}$ Nota de Nougué/Sánchez: "QUE SAIBAM AS LINHAS COM QUE SE COSEM: 'que conheçam os apuros em se vêem"” (Cervantes, tradução Nougué/Sánchez, 2005:260, maiúsculas e aspas dos autores).

${ }^{74}$ Nota de Nougué/Sánchez: “Aparece aqui pela primeira vez uma das mais marcantes características de Sancho, qual seja, o expressar-se por meio de seqüências vertiginosas de provérbios e expressões. Esta característica, porém, só voltará a aparecer, e com toda a força, no livro II" (Cervantes, tradução Nougué/Sánchez, 2005: 260, caixa alta e aspas dos autores).
} 


\section{Considerações finais}

Ao analisar os paratextos e/ou metatextos sobre as diferentes traduções dentro do ponto de vista de estratégias e opções de tradução e dos conceitos de estrangeirização e domesticação ${ }^{75}$ notam-se algumas coincidências entre o que é dito, como também certas discrepâncias entre a proposta inicial e o resultado obtido. As traduções do Quixote poderiam, à primeira vista, ser classificadas como antigas, ou seja, mais próximas ao leitor contemporâneo da edição, ou recentes, ou seja, mais próximas ao texto, mas não é essa a conclusão a que se chega ao fim da apreciação do cotejo.

A tradução anônima é criticada em um metatexto ${ }^{76}$ sobre a tradução dos "escrupulosos" Viscondes/Chagas. Embora a tradução de Andrade/Amado seja apontada como "tradução brasileira"77 e com "estilo brasileiro", também é mencionado que os tradutores tiveram "maior zelo e estima" pelo romance ${ }^{78}$, que como "escrupuloso", sugere um apego ao texto de origem.

A tradução de Ribeiro é a única que se apresenta com a proposta explícita de "nacionalizar" o Quixote, como foi visto antes, mas mesmo assim Morejón (1963) afirma que, "sem trair nunca o conceito nem o espírito cervantino, [Ribeiro] escreveu um Quixote que é tão português como espanhol, pois foi repensado a partir de um ângulo genuinamente lusitano" (Morejón in Cervantes, 1963:22-23). Cabe notar que, para Morejón, o fato de o texto ser tão português como espanhol deve-se a ter sido repensado a partir de um ângulo lusitano; algo que nos remete à influência de 250 anos de bilinguismo luso-espanhol, tanto linguístico como cultural ${ }^{79}$.

\footnotetext{
${ }^{75}$ Lawrence Venuti também escreve sobre estratégias de tradução: "Strategies in producing translations inevitably emerge in response to domestic cultural situations. But some are deliberately domesticating in their handling of the foreign text, while others can be described as foreignizing, motivated by an impulse to preserve linguistic and cultural differences by deviating from prevailing domestic values" (Venuti, 2005: 240). Ver timber_Antoine Berman (2007).

${ }^{76}$ Para Peixoto são: "tradutores escrupulosos e de prosa escorreita. Levados talvez pela inferioridade em que viam as nossas letras no capítulo das traduções do Quixote"” (Peixoto, 1961, apud Abreu, 1994: 8283, grifos meus).

${ }^{77}$ No ano seguinte, publicou o que se afirmava ser a primeira tradução brasileira de D. Quixote. “[...] A tradução foi de Almir de Andrade e Milton Amado. A idéia de publicar uma edição de D. Quixote partiu de Daniel, irmão de José Olympio, e conta-se que este, ao vê-lo trabalhando nisso, teria resmungado: 'A mim o que interessa mesmo é o Brasil"” (Hallewell, 2005: 465, aspas do autor).

${ }^{78}$ Nota da primeira edição: "Como se vê, esta é a primeira vez que se traduz no Brasil o Dom Quixote. [...] A complexa e árdua missão de verter em boa língua portuguêsa mas com estilo brasileiro (como a propósito de Alencar assinalou o Prof. Gladstone Chaves de Melo) o Dom Quixote foi confiada a dois escritores que a realizaram com o maior zêlo e a estima profunda que têm pelo romance [...]" (Cervantes, tradução Andrade/Amado, 1952: 86, itálicos da edição).

${ }^{79}$ Ver mais sobre o bilinguismo e a tradução do Quixote em Cobelo (2010).
} 
Na tradução de Eugênio Amado, Morejón (1991) ${ }^{80}$ diz que o tradutor tenta respeitar a estrutura da linguagem cervantina, substituindo formas hispânicas por refrões e locuções brasileiras, com o objetivo de trazer uma "melhor compreensão do estilo do Cervantes", o que considera uma tradução honesta, sem liberalidades que alterem a estrutura ou o conteúdo do livro. Cabe ressaltar novamente a preocupação em encontrar equivalentes brasileiros para as formas hispânicas, uma estratégia considerada domesticadora, aqui usada com o intuito de não se afastar do estilo do autor espanhol.

Como foi visto, as traduções do século XXI se declaram mais próximas ao texto. Há em seus paratextos grande preocupação com o texto cervantino, mas curiosamente possuem um discurso parecido ao dos paratextos das traduções anteriores no que diz respeito ao objetivo de atender às expectativas do leitor contemporâneo e de empregar linguagem atual, uma preocupação corrente, geralmente encontrada nas edições que tencionam aproximar o texto do leitor. A edição da editora 34 é apresentada como a primeira versão que faria "jus à riqueza do original", precisamente por reproduzir, e recuperar para o leitor de hoje, as características da prosa cervantina, toda sua a graça o encantamento $^{81}$. Molina diz manter as construções sintáticas [em português] mesmo que pareçam espanholizantes, comparando-as ao português clássico, e fala em ponte com a prosa de Cervantes. Segundo ele, isso não teria sido feito pelas traduções anteriores, que não seriam "ruins" e teriam se esforçado para ser "leves", mas por terem partido do pressuposto que Cervantes escreveria mal, de maneira antigramatical e confusa ${ }^{82}$ e de que o texto deveria ser corrigido, seus excessos eliminados, exemplificando com as censuras de "partes mais fortes" na tradução Viscondes/Chagas ${ }^{83}$. Apesar de supor que

\footnotetext{
80 "A tradução que temos neste instante diante de nós, realizada por Eugênio Amado, tenta respeitar, na medida do possível - em tradução literária é necessário falar sempre "na medida do possível" - a estrutura da linguagem cervantina, substituindo formas hispânicas por sintagmas, modismos, refrões, locuções brasileiras, para melhor compreensão do estilo do Cervantes. A tradução de Eugênio Amado respira honestidade por todos os lados, e em nenhum instante se permite o tradutor liberalidades que alterem a estrutura ou o conteúdo do livro de Cervantes. Trata-se de uma tradução harmônica, feita com equilíbrio, que aponta diretamente o alvo, que é a compreensão séria e inteligente do Quixote por parte dos leitores brasileiros, oferecendo-nos a magna obra cervantina como todo o sabor e a riqueza que caracterizam o original, guardando as distâncias, evidentemente, que todas as traduções, até aquelas consideradas absolutamente perfeitas - nas quais jamais acreditaremos a não ser que compreendamos ou aceitemos os resultados como uma outra obra de arte - guardam como o original" (Morejón in Cervantes, 1991: xxvii).

${ }^{81}$ Ver nota 46.

${ }^{82}$ Ver comentário de Berman (2005: 279):“[...] the masterworks of prose are characterized by a kind of "bad writing," a certain "lack of control" in their texture. This can be seen in Rabelais, Cervantes, [...]".

${ }^{83}$ Villa, Benedetti \& Hirsch, (2003: 165): “[...] as traduções disponíveis [o tradutor mencionou anteriormente Viscondes/Chagas, Almir de Andrade \& Milton e Eugênio Amado] não conseguiram fazer a ponte. Não que elas sejam ruins, todas se esforçam para ser leves, mas lhes falta alguma coisa. Durante muito tempo, fiquei pensando nisso, em qual seria essa falha. Hoje sei que o problema é principalmente formal: não se respeita o ritmo da prosa de Cervantes. Em todas [as traduções] se partiu do pressuposto
} 
"nenhuma tradução chegava bem junto ao leitor brasileiro contemporâneo" (Villa, Benedetti \& Hirsch, 2003:160), e que as "traduções anteriores soavam antiquadas, distantes" (ibid, p. 167) confirma que todas foram "uma referência importante durante o trabalho" (ibid, p. 161).

Essas declarações remetem à edição da editora Record, que se propõe a traduzir em "belo acento brasileiro da língua de Camões" toda a riqueza de Cervantes ${ }^{84}$. Nougué/Sánchez mencionam uma "equação de três incógnitas", o português contemporâneo a Cervantes, o sabor hispânico e a compreensão do leitor atual.

Ao analisar as traduções verifica-se que essa oposição entre duas estratégias, domesticação e estrangeirização, não se reflete de maneira rígida nas opções tradutórias. A tradução anônima salta aos olhos como a mais literal com relação ao texto em espanhol, característica comumente encontrada nas traduções arcaicas, e a de Ribeiro como a mais domesticadora, cumprindo seu intento de fazer uma versão portuguesa do Quixote. As outras traduções flutuam entre uma estratégia e outra, em especial buscando de provérbios equivalentes na língua portuguesa, ou explicitando o sentido do mesmo, recursos que levam o texto ao leitor e não o inverso. A literalidade surge, quase sempre, em duas situações: quando não existe um equivalente, possibilitando então o sabor estrangeiro do texto de Cervantes, ou quando existe um provérbio em português que é idêntico a uma tradução literal do provérbio do texto de partida. ${ }^{85}$

Logo na primeira frase, Ni yo lo digo ni lo pienso, aparece um lusismo, o uso do termo cá, nas traduções portuguesas assinadas e em Nougué/Sánchez. Allá se lo hayan, con su pan se lo coman, considerado como o primeiro provérbio dos sete que Sancho dirá nesse segmento, é parte de um provérbio que aconselha a não intromissão na vida alheia. É traduzido com literalidade só pelo tradutor anônimo. Apesar de que o termo “se hajam" ainda ser usado na segunda metade do século XIX ${ }^{86}$, a tradução de 1876, bem como os tradutores do século XX utilizam parte do início do refrão original, se avenham $^{87}$. A segunda parte, com mudanças no segmento final da frase, é uma

obsoleto de que Cervantes escreve mal - idéia, aliás que alguns repetem até hoje -, de que ele é antigramatical, confuso, repetitivo e redundante. Por isso o tradutor teria, antes demais nada, que corrigir o texto. Em todas essas traduções foram feitas 'correções', eliminando repetições e redundâncias, limitando excessos. Os viscondes até censuram as partes mais fortes: cortam palavrões, desfazem duplos sentidos maliciosos [...]" (aspas dos autores).

${ }^{84}$ Ver texto integral na nota 59.

${ }^{85}$ Ver mais em Cobelo (2010b).

${ }^{86}$ Cfr. Ordenações e leis do reino de Portugal (1865:244).

87 O provérbio inteiro diz: "lá se avenham, lá se hajam". Disponível em: http://www.infopedia.pt/portugues-frances/1\%C3\%A1. Acesso em: 7 set. 2010. 
expressão, traduzida por Andrade/Amado e por Nougué/Sánchez (com uso de nota explicativa) com variações do provérbio Cada um sabe as linhas com que cose, e Ribeiro é o único que separa completamente a segunda oração com um ponto final e a traduz por um provérbio bem rimado e conhecido, Sua alma, sua palma. Só Molina une as duas expressões, Eles lá que saibam as linhas com que cosem, uma solução também interessante.

Logo nota-se o uso de porquear por Ribeiro no lugar que todos deixaram amancebados, e a seguir o segundo provérbio, De mis viñas vengo, no sé nada. Na tradução anônima, vê-se novamente a literalidade, repetida nas traduções brasileiras do século XX. A segunda parte, não sei nada, aparece em todas as outras traduções (às vezes com o acréscimo da preposição de), exceto na de Ribeiro, que inclui a expressão seguinte, e resolve tudo com o provérbio: Não gosto de meter o nariz na vida alheia. $\mathrm{O}$ terceiro provérbio, que el que compra y miente, en su bolsa lo siente, é traduzido literalmente e de forma bem parecida por quase $\operatorname{todos}^{88}$. Nesse caso a tradução literal resulta também em um provérbio. Nougué/Sánchez preferem usar uma variante de outro provérbio, também considerado como equivalente, quem mexe em vespeiro, picado sairá.

Cuanto más, que desnudo nací, desnudo me hallo: ni pierdo ni gano, provérbio de reminiscências bíblicas e quase um bordão de Sancho Pança, é traduzido de maneira bem literal por quase todos, com pequenas variações. A exceção é de Ribeiro, por mim tanto se me dá como se me deu. Onde elas se fazem, lá se pagam, que coloca dois provérbios no lugar. O próximo provérbio, $Y$ muchos piensan que hay tocinos, y no hay estacas, dito cinco vezes pelo escudeiro durante a obra, é bem marcado cultural e historicamente $^{89}$. Nesse caso a tradução anônima é menos literal que a tradução Viscondes/Chagas, seguida das traduções de Eugênio Amado, e de Andrade/Amado. As edições atuais, assim como a da tradução de Ribeiro usaram variações de um provérbio equivalente: São mais as vozes que as nozes (Molina) e nem tudo o que reluz é ouro (Nougué/Sánchez).

A seguir Sancho diz: ¿quién puede poner puertas al campo?, outro provérbio não encontrado em português nas referências usadas ${ }^{90}$. Segundo Anna Sanchez "indica a impossibilidade de evitar a maledicência ou de limitar a fantasia (1982: 180),

\footnotetext{
${ }^{88}$ As traduções brasileiras suprimem o pronome pessoal feminino sua.

${ }^{89}$ Ver explicação da nota 70.

${ }^{90}$ Ver item 3.2.5 - Coletâneas e Dicionários de Provérbios em Cobelo (2009:94-95).
} 
interpretação dada no século XIX e até 1963, através de três expressões distintas. Eugênio Amado retorna à opção literal da tradução anônima, e no século XXI, as duas versões são quase idênticas; Molina usa quem pode rédeas ao vento, assim como Nougué/Sánchez, apenas com travas no lugar de rédeas.

O último provérbio, Cuanto más que de Dios dijeron, fixou-se, assim como muitos outros provérbios da obra, através do próprio Quixote, e não se encontrou um provérbio conhecido em português. As opções dos tradutores foram bastante semelhantes. Todos entenderam o significado do dito popular, inclusive o fato de ser um complemento do anterior, mas as escolhas variam entre a total literalidade, como na anônima, e gradações da mesma, como em Andrade/Amado, resultando uma opção bastante adequada em Nougué/Sánchez, Tanto mais que até de Deus murmuraram, uma escolha fundamentada na nota de Rico ${ }^{91}$, também acompanhada de nota de rodapé nesta edição da Record. As traduções portuguesas também explicitam o provérbio, e chamam a atenção pela inserção do nome de Cristo.

A tradução que se destaca por sua proposta adaptativa na resposta de don Quixote, - ¡Válame Dios - dijo don Quijote - y qué de necedades vas, Sancho, ensartando! ¿Qué va de lo que tratamos a los refranes que enhilas? é a de Ribeiro, que traduz a primeira expressão por uma bem portuguesa: Santo Breve da marca, e a seguir usa, para asneiras és um barra! De todo chorrilho de rifões nenhum acertou a carapuça, adicionando um adjetivo a Sancho e arrematando a segunda frase com uma expressão idiomática conhecida em português, também usada no Brasil. As outras traduções seguem bastante o texto de Cervantes; cabe notar que só os tradutores do século XXI usam a acepção mais literal, necedades; as outras preferem sandices, tolices e disparates. Na última frase a diferença mais evidente é no termo refrán, cuja tradução mais aceita, provérbio (anônima e Nougué/Sánchez), prefere-se à refrão (traduções brasileiras) ou rifão - um termo polissêmico. Viscondes/Chagas e Molina usam os sinônimos adágios e ditados, respectivamente.

Conclui-se que, pelo menos em relação aos provérbios, as traduções flutuam entre as duas estratégias, aproximando-se ora do texto, ora do leitor, variando a estratégia dentro de uma só lógica: aproximar-se do seu leitor contemporâneo. Isso pode significar ter que domesticar para um público que demande um "texto nacional" ou

\footnotetext{
${ }^{91}$ Ver nota 71
} 
estrangeirizar para um leitor interessado em sentir mais de perto o sabor do texto de Cervantes.

\section{Referências bibliográficas}

ABREU, Maria Fernanda de. Cervantes no Romantismo Português. Lisboa: Editorial Estampa, 1994.

O Quixote na voz dos escritores portugueses. In: VIEIRA, Maria Augusta da Costa (Org.) Dom Quixote: a letra e os caminhos. São Paulo: EDUSP, 2006.

ALMEIDA, Henrique. Tradução ou adaptação? - A versão de Aquilino Ribeiro de Autores Clássicos. Mathesis n. 15, 2006 Disponível em: http://z3950.crb.ucp.pt/biblioteca/Mathesis/Mat15/Mathesis15 127.pdf. Acesso em 02 jul. 2009.

BARROSO, Ivo. Edgar Allan Poe, "Filosofia da composição". O Corvo e suas traduções. Rio de Janeiro: Lacerda Editores, 1998.

BERMAN, Antoine. A prova do estrangeiro. Tradução de Maria Emilia Pereira Chanut. Bauru, SP: EDUSC. 2002.

Translation and the trials of the foreing. In: VENUTI, Lawrence (Ed.). The traslation studies reader. 2nd Edition. New York: Routledge, 2005. p. 276-289.

BORGES, Jorge Luís. Mi entrañable señor Cervantes. Conferência na Universidade de Texas, Austin, $1968 . \quad$ Disponível em: www.analitica.com/Bitblio/jjborges/cervantes.asp. Acesso em 21 abr. 2008.

CAÑETE, Carmen $\mathrm{M}^{\mathrm{a}}$ Comino Fernández de. Primera aproximación al Vizconde de Benalcanfor y a su traducción de Don Quixote de la Mancha. In DASILVA, Xosé Manuel (Ed.). Perfiles de la traducción hispano-portuguesa, II. Vigo: Editorial Academia del Hispanismo, pp. 59-68, 2007. In: Actas del I Congreso de la Asociación de Lusitanistas del Estado Español. Palma de Mayorca: Universitat de les Illes $\quad$ Balears, 2003. Disponível em: http://www.emblematica.com/alee/actas.pdf. Acesso em 07 jul. 2010.

CERVANTES SAAVEDRA, Miguel de. EI Ingenioso Hidalgo Don Quijote de la Mancha. Editor Francisco Rico. Barcelona: Ed. Crítica, 2001.

Dom Quixote de la Mancha. Tradução de Almir de Andrade e Milton Amado. Rio de Janeiro: José Olympio, 1952 e 1958.

. O Engenhoso Fidalgo Dom Quixote de la Mancha. Tradução de Aquilino Ribeiro. São Paulo: Difusão Européia do Livro, 1963.

O Engenhoso Fidalgo Dom Quixote De La Mancha. Tradução de Eugenio Amado. Belo Horizonte: Villa Rica, 1991 e 2005. 
Dom Quixote de la Mancha. Tradução de Visconde de Castilho e de Azevedo. São Paulo, Edições Cultura, 1942 e 1943.

Dom Quixote de la Mancha. Tradução de Viscondes de Castilho e de Azevedo. São Paulo: Abril Cultural, 1978.

O engenhoso fidalgo D. Quixote da Mancha. Tradução de Carlos Nougué e José Luís Sánchez. Rio de Janeiro: Record, 2005.

O engenhoso cavaleiro D. Quixote de La Mancha. Tradução de Sérgio Molina. Edição bilíngue. São Paulo: Editora 34, 2005 e 2007.

O Engenhoso Fidalgo Dom Quixote de la Mancha. Tradução anônima. Lisboa: Typografia Rollandiana, 1794. (Digitalizado pela Oxford University, 2007).

CINTRÃO, Heloísa Pezza. Colocar Lupas, Transcriar Mapas - Iniciando o desenvolvimento da competência tradutória em nível básico de espanhol como LE. São Paulo, 2006. Tese (Doutorado em Letras). Faculdade de Filosofia, Letras e Ciências Humanas, Universidade de São Paulo.

COBELO, Silvia. Historiografia das traduções do Quixote publicadas no Brasil. São Paulo, 2009. Dissertação (Mestrado em Letras). Faculdade de Filosofia, Letras e Ciências Humanas, Universidade de São Paulo.

A tradução tardia do Quixote em Portugal. Aceito em ago. 2010. TradTerm. São Paulo: CITRAT/FFLCH-USP.

A tradução de provérbios e a busca de equivalência. Submetido em set. 2010b para publicação em Tópicos del Seminario. Puebla: Benemérita Universidad Autónoma de Puebla ses@siu.buap.mx.

CORRAL, Francisco. Apresentação. In CERVANTES. O engenhoso cavaleiro D. Quixote de La Mancha. Tradução de Sérgio Molina. Edição bilíngue. São Paulo: Editora 34, 2005.

DANELON, Fernanda. O Google dos Sebos. Revista Trip, $\mathrm{n}^{\circ}$ 177. Reportagens, Assunto: Livros. Publicado em 13 mai. 2009. Disponível em: http://revistatrip.uol.com.br/revista/177/reportagens/o-google-dos-sebos.html. Acesso em 20 jun. 2009.

ESTANTE Virtual. Disponível em: http://www.estantevirtual.com.br/. Acesso em 27 ago. 2010.

HALLEWELL, Laurence. O livro no Brasil: sua história. Tradução de Maria da Penha Villalobos, Lólio Lourenço de Oliveira e Geraldo Gérson de Souza. 2a . ed.. São Paulo: EDUSP, 2005. 
LIVIA, Márcia. Estante Virtual adota pagamento digital. Baguette.com. Publicado em 08 dez 2008. Disponível em: www.baguete.com.br/noticiasDetalhes.php?id=31076. Acesso em 20 jun. 2009.

LOSSO, Tiago. Estado e democracia no discurso oficial do Estado Novo. Política \& Sociedade, América do Sul, 7. Publicado em 23 out. 2008. Disponível em: www.periodicos.ufsc.br/index.php/politica/article/view/7644/6997. Acesso em 10 jul. 2009.

MARTINS, Marcia A.P. A instrumentalidade dos estudos descritivos para a análise de traduções: o caso dos Hamlets brasileiros. São Paulo, 1999. 324p. Tese (Doutorado em Comunicação e Semiótica) - Programa de Estudos Pós-Graduados em Comunicação e Semiótica, Pontifícia Universidade Católica de São Paulo. Disponível em: www.letras.puc-rio.br:8081/pdfs/hamlets brasileiros.pdf. Acesso em 30 mai. 2009.

Shakespeare no Brasil: traduções brasileiras do cânone shakespeariano. Anais do XI Congresso Internacional da ABRALIC. São Paulo, 13 a 17 de julho de 2008. Disponível em: em: www.abralic.org.br/cong2008/AnaisOnline/simposios/pdf/065/MARCIA_MARTI NS.pdf. Acesso em 28 mai. 2009.

Escolha seu Shakespeare. Portal disponível em: http://www.letras.pucrio.br:8081/.

MILTON, John. O poder da tradução. São Paulo: Ars Poetica, 1993.

MILTON, John e TORRES, Marie-Hélène. Bibliografia sobre Tradução, retradução e adaptação. Cadernos de Tradução, Vol. 1, $\mathrm{n}^{\circ}$ 11, 2003. Disponível em: www.periodicos.ufsc.br/index.php/traducao/article/viewFile/6186/5741. Acesso em 21 mai. 2009.

MOREJÓN, Julio Garcia. Cervantes e o 'Quixote'. In: CERVANTES SAAVEDRA, Miguel de. O Engenhoso Fidalgo Dom Quixote De La Mancha. Traduzido por Aquilino Ribeiro. São Paulo: Difusão Européia do Livro, 1963.

A Universalidade de Cervantes. In: CERVANTES SAAVEDRA, Miguel de. O Engenhoso Fidalgo Dom Quixote De La Mancha. Tradução de Eugenio Amado. Belo Horizonte: Villa Rica, 1991

NOVA TRADUÇÃO da obra de Cervantes remete texto ao português arcaico. $14 \mathrm{dez}$ 2008 (fonte: Redação Folha de São Paulo, São Paulo, 14 jan. 2006). Disponível em: http://www.fndc.org.br/internas.php?p=noticias\&cont_key=5361. Acesso em 14 dez. 2008.

O ENGENHOSO Fidalgo D. Quixote da Mancha. Letras e Livros. 16 dez 2008. Disponível em: http://www.letraselivros.com.br/index2.php?option=com_content\&do_pdf=1\&id= 20. Acesso em 29 jan. 2009. 
ORDENAÇÕES e leis do reino de Portugal. Coimbra: Imprensa da Universidade, 1865. Disponível

http://books.google.com.br/books?id=fq8WAAAAYAAJ\&pg=PA244\&lpg=PA24 $4 \& d q=\% 221 \% \mathrm{C} 3 \% \mathrm{~A} 1+$ se + hajam $\% 22 \&$ source=bl\&ots=fpFYdKmUo_\&sig=bmH CKYDz5CmvsqgyT9D09598X1Q\&hl=pt-

BR\&ei=z12JTOiFGZPy9QTSiKXhDg\&sa=X\&oi=book_result\&ct=result\&resnu $\underline{m}=1 \& v e d=0$ CCoQ6AEwAA\#v=onepage $\& \mathrm{q}=\% 221 \% \mathrm{C} 3 \% \mathrm{~A} 1 \% 20 \mathrm{se} \% 20$ hajam $\% 2$ 2\&f=false. Acesso em: 7 set. 2010.

PAES, José Paulo. Tradução, a ponte necessária. Aspectos e problemas da arte de traduzir. São Paulo: Ática, 1990.

PÉREZ RODRIGUEZ, Marta. Tras un siglo de recepción cervantina en Brasil: Estudios críticos sobre el Quijote (1900-2000). São Paulo, 2007. Dissertação (Mestrado em Letras) -Faculdade de Filosofia, Letras e Ciências Humanas, Universidade de São Paulo.

PINHEIRO CHAGAS, Manuel. Ensaios Críticos. Porto: Typografia Commercial, 1866.

POUPAUD, Sandra; PYM, Anthony; SIMÓN, Ester Torres. Finding translations. On the use of bibliographical databases in translation history. Disponível em: http://www.tinet.org/ apym/online/research_methods/2008_databases_paper_ME TA revised.pdf. Acesso em 20 maio 2009.

PYM, Anthony. Method in Translation History. Manchester: St. Jerome, 1998.

Humanizing Translation History. Disponível em: http://www.tinet.org/ apym/online/research_methods/2008_humanizing_historyh ermes.pdf. Acesso em 20 maio 2009.

RIBEIRO, Aquilino. Prefácio. In: CERVANTES SAAVEDRA, Miguel de. Dom Quixote de la Mancha. Traduzido por Aquilino Ribeiro. São Paulo: Difusão Européia do Livro, 1963.

VENUTI, Lawrence (Ed.). The Translation Studies Reader. 2nd Edition. London/New York: Routledge, 2005.

. Strategies of translation. In: BAKER, Mona (Ed.) Routledge Encyclopedia of Translation Studies. 2nd Edition. London/New York: Routledge, p.482-502, 2005.

VIEIRA, Maria Augusta da Costa (org.). Dom Quixote - A letra e os caminhos. São Paulo: Edusp, 2006.

VILLA, Dirceu; BENEDETTI, Ivone; HIRSCH, Irene. Entrevista com Sérgio Molina in Cadernos de Literatura em Tradução. São Paulo: Humanitas/FFLCH-USP, n. 5, p. 171, 2003. 
SANCHEZ, Anna. Os refrãos no discurso de Sancho Pança: um estudo semântico. São Paulo, 1982. Dissertação (Mestrado em Letras). Faculdade de Filosofia, Letras e Ciências Humanas, Universidade de São Paulo.

SOUZA, Alex. Nova Tradução da obra de Cervantes remete texto ao português arcaico. Diário de Natal. Natal, 18 jan. 2006. Caderno "Muito", p. 4.

WOODSWORTH, Judith. History of translation. In: BAKER, Mona (Ed.) Routledge Encyclopedia of Translation Studies. 2nd Edition. London/New York: Routledge, p.100-106, 2005. 